\title{
ITER Relevant High Heat Flux Testing on Plasma Facing Surfaces
}

\author{
Takeshi Hirai ${ }^{1}$, Koichiro Ezato ${ }^{2}$ and Patrick Majerus ${ }^{1}$ \\ ${ }^{1}$ IWV2 Forschungszentrum Jülich GmbH, EURATOM-Association, 52425 Jülich, Germany \\ ${ }^{2}$ JAERI, Naka Fusion Research Establishment, Naka-machi Naka-gun, Ibaraki 311-0193, Japan
}

The current ITER design employs beryllium, carbon fiber reinforced composite and tungsten as plasma facing materials. Since these materials are exposed to high heat fluxes during the operation, it is essential to perform high heat flux tests for R\&D of ITER components. Static heat loads corresponding to cycling loads during normal operation, are estimated to be up to $20 \mathrm{MW} / \mathrm{m}^{2}$ in the divertor targets and around $0.5 \mathrm{MW} / \mathrm{m}^{2}$ at the first wall in ITER. For the static high heat flux testing, tests in electron beam facilities, particle beam facilities, IR heater and in-pile tests have been performed. Another type, more critical heat loads, which have high power densities and short durations, corresponding to transient events, i.e. plasma disruption, vertical displacement events (VDEs) and edge localized modes (ELMs) deliver considerable heat flux onto the plasma facing materials. For this purpose, tests in electron beam (short pulses), plasma gun and high power laser facilities have been carried out. The present work summarizes the features of these facilities and recent experimental results as well as the current selection of ITER plasma facing components.

(Received October 26, 2004; Accepted January 20, 2005)

Keywords: fusion, (ITER) high heat flux, plasma facing materials, plasma facing components, coating, thermal fatigue, thermal shock, nondestructive examination, electron beam, particle beam, Infrared heater, In-pile tests, plasma gun, laser

\section{Introduction}

The joint project of the next step fusion device, ITER has been initiated in 1986. It is a continuous effort of scientific and technological research from the EU, Japan, the USA, Canada and Russia. Recently China and South Korea have joined the project. Thanks to intensive R\&D programs, ITER is now ready for construction. ITER will be the first fusion device with significant $\mathrm{Q}$ (ratio of fusion power to additional heating power) and extended to D-T burning. The design of ITER relies on a solid and robust basis of experimental results and sophisticated modelling. ${ }^{1)}$ However, there are still a number of issues for which the existing database is still fragmentary or which are critical on the basis of extrapolation from present fusion devices. The longer pulse duration and cumulative run-time, together with the higher heat loads during normal operation and more intense transient heat loads, plasma disruptions and vertical displacement events (VDEs) represent the largest changes in the operation conditions compared to current experiments. These issues as well as radiation damage due to $14 \mathrm{MeV}$ fusion neutron, need to be addressed in dedicated experiments on existing fusion facilities in parallel to the ongoing simulation experiments and have to be implemented into the ITER design at a given time.

Design studies for ITER are based on the technical feasibilities of plasma facing components (PFCs) which can guarantee a reasonable lifetime from safety and economical points of view. This lifetime is limited mainly by thermal loads and by thermally induced mechanical stresses to these components. Here thermal fatigue during the cyclic plasma operation at power density of 5 to $20 \mathrm{MW} / \mathrm{m}^{2}$ for the divertor targets $\left(\sim 0.5 \mathrm{MW} / \mathrm{m}^{2}\right.$ for the first wall) are a serious concern, in particular for discontinuously operating tokamak devices. Transient heat loads, such as plasma disruptions will deposit energy densities of several ten $\mathrm{MJ} / \mathrm{m}^{2}$, these events with pulse durations in the order of $1 \mathrm{~ms}$ will damage and erode the divertor, especially in the separatrix strike zone. Further transient events which will deposit a large fraction of the plasma energy $\left(\sim 60 \mathrm{MJ} / \mathrm{m}^{2}\right)$ on relatively small wall areas (pulse duration typically $100 . .300 \mathrm{~ms}$ ) are the vertical displacement events (VDEs). The quasi-continuous plasma operation in large future confinement experiments is associated with another transient heat load event, namely type-I ELMs (Edge localized modes) which will deposit a nonnegligible amount of energy during each event, the expected power deposition is repeated a frequency of about $1 \mathrm{~Hz}$, in the order of $1 \mathrm{MJ} / \mathrm{m}^{2}$ within a sub-millisecond time scale. ${ }^{2)}$ These ITER relevant heat load conditions are summarized in Fig. 1. In addition to the heat loads, $14 \mathrm{MeV}$ neutrons result in radiation damage. The predicted maximum neutron damage in beryllium (Be) is $\sim 1.5 \mathrm{dpa}, 1500 \mathrm{appm} \mathrm{He}$, and an operation temperature for the first wall is $\sim 200-300^{\circ} \mathrm{C}$ (for the limiter the maximum temperature during start up: $\sim 700^{\circ} \mathrm{C}$ ). Radiation damage is calculated to be $\sim 0.1 \mathrm{dpa}$ at the operation temperature $\sim 200-1300^{\circ} \mathrm{C}$ in tungsten (W) and $<0.1 \mathrm{dpa}$ at $\sim 200-1500^{\circ} \mathrm{C}$ in carbon fiber reinforced composite (CFC) (taking into account the replacements of the divertor cassettes). ${ }^{3}$ Thus, it is essential to study the performances of the materials and components under these

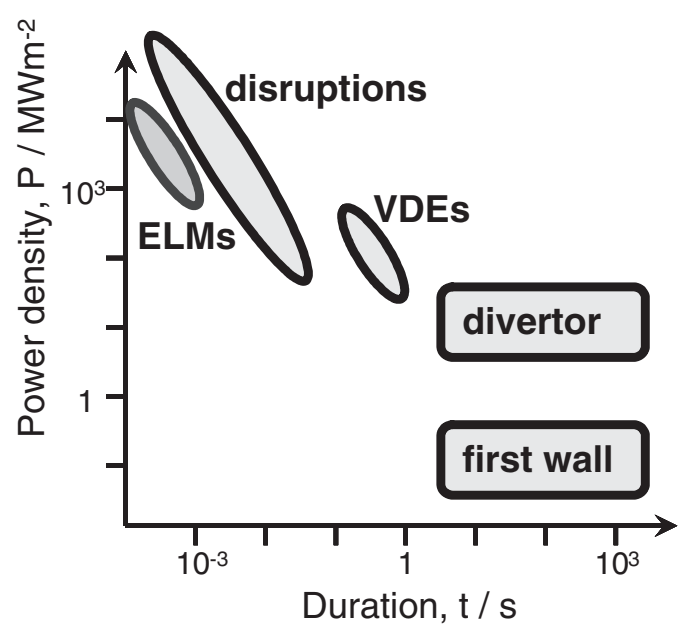

Fig. 1 Plasma induced thermal loads on plasma facing surfaces in ITER. 
conditions.

For simulation of the ITER relevant high heat fluxes, a number of different types of heat sources have been applied, e.g. electron beam facilities, particle beam facilities, IR heaters, plasma guns. Each heat source has different specification which is associated with the advantages and disadvantages. The present paper focuses on high heat flux testing by various heat sources. Section 2 summarizes briefly candidate plasma facing materials (PFMs) and options of PFCs. Section 3 describes static heat load testing such as screening and thermal fatigue tests. Section 4 summarizes transient heat load experiments, namely, thermal shock experiments which are corresponding to transient events.

\section{Plasma Facing Materials and Components in ITER}

PFMs, so-called armors, joint to coolant tube or a heat sink made of $\mathrm{Cu}$-alloy with water cooling channels. Currently, the ITER design employs several PFMs selected for their suitability to regions of the vacuum vessel with different power and particle loading characteristics. Be is the prime candidate material for the first-wall, whereas, $\mathrm{W}$ is the preferred material for the divertor, except for the area near the strike points where CFC will be used. Figure 2 shows the poloidal cross section of ITER. Be, $\mathrm{W}$ and $\mathrm{CFC}$ armored area are to be about $700 \mathrm{~m}^{2}, 70 \mathrm{~m}^{2}$ and $50 \mathrm{~m}^{2}$, respectively. ${ }^{4)}$ Each of these candidate materials has inherent advantages and disadvantages. ${ }^{1)}$ Be has been selected as the armor of the first wall since it is a low $\mathrm{Z}$ material which is less harmful to the fusion plasma and it is a good oxygen getter. $\mathrm{W}$ has advantages because of the high melting point and low erosion

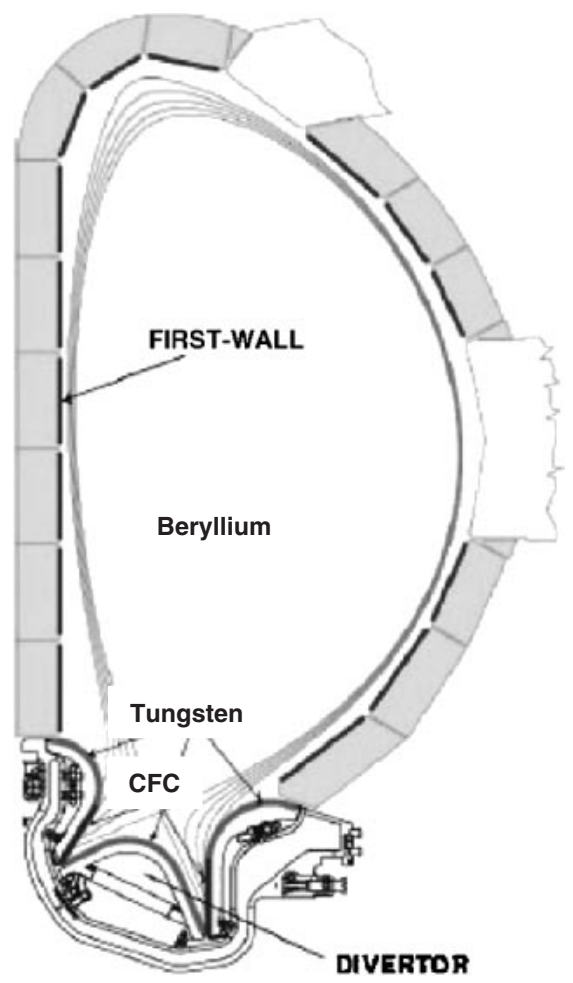

Fig. 2 Poloidal cross section showing the layout of PFCs in ITER with different armor materials. rate under high flux hydrogen isotope bombardment in the divertor. However, the operational lifetime of $\mathrm{W}$ in this region is uncertainty due to melt layer loss under transient heat loads. Thus, CFC is primarily chosen because of its high thermal shock resistance.

In the frame of ITER R\&D activities, main target of developing high heat flux components of divertor have been highlighted: (1) Evaluation of the different armor material grades and the selection of the reference grade for the ITER, (2) Justification of the material performance at ITER specific conditions (thermal fatigue/thermal shock resistance, neutron irradiation effect, etc.), (3) Demonstration of their durability of the joints between plasma-facing materials and heat sinks. The current status of $\mathrm{R} \& \mathrm{D}$ on plasma facing materials and components are comprehensively summarized in recent review papers. ${ }^{5-9}$ ) The followings are a brief summary of the currently promising options for ITER PFCs and non-destructive examinations applied during manufacturing.

\subsection{Be materials and the components}

Studies based on thermal fatigue and thermal shock resistance indicated that the most promising Be grades is "vacuum hot pressed" S-65C provided by Brush Wellman (US), and DShG-200 (Russia) as an option. S65-C grade has been selected as a reference material due to the lowest $\mathrm{BeO}$ and metallic impurities contents, and high ductility at elevated temperatures. ${ }^{10)}$

Be (thickness of $\sim 10 \mathrm{~mm}$ ) is possible to join directly to the $\mathrm{Cu}$ alloy heat sink without OFHC (oxygen free high conductivity)- $\mathrm{Cu}$ interlayer because its thermal expansion coefficient does not differ from that of $\mathrm{Cu}$ very much. However, Be reacts with almost all metals and forms brittle intermetallic compounds. To suppress the intermetallic compounds during joining processes, optimized process parameters have been developed with diffusion barriers such as titanium interlayer. R\&D, different interlayers and various processes (brazing and hot isotropic press (HIP)), have been attempted. ${ }^{7,11-14)}$ A new technology, fast brazing, has been developed by the Efremov institute (Russia). ${ }^{15)}$ Here the rapid temperature ramping rate (typically $160-180 \mathrm{~K} / \mathrm{min}$. in heating phase and $20 \mathrm{~K} / \mathrm{min}$. in cooling phase) is realized by an electron beam facility, TSEFEY, ${ }^{16)}$ Efremov Institute (Russia). Because of the short brazing time, formation of brittle intermetallic zone was considerably suppressed. ${ }^{15)}$ The Be mock-ups $(20 \mathrm{~mm} \times 20 \mathrm{~mm})$ showed excellent thermal fatigue performances up to $8 \mathrm{MW} / \mathrm{m}^{2} .{ }^{17)}$ The ITER design adopted a first wall panel of the size of $1100 \mathrm{~mm} \times$ $350 \mathrm{~mm} .{ }^{18)}$ This is orders of magnitude larger than the size of current small-scale and medium-scale mock-up (around $100 \mathrm{~mm} \times 100 \mathrm{~mm}$ ), thus, scale-up of Be mock-up is a technological challenge, presently.

Alternative option is Be coatings on heat sinks. Vacuum plasma spray (VPS) Be coating has been developed in LANL (US). ${ }^{19)}$ After optimization of the coating condition, $12 \mathrm{~mm}$ thick VPS-Be coating which has $98 \%$ of bulk Be density and $94 \%$ of thermal diffusivity of bulk Be were achieved. ${ }^{20)}$ The heat flux tests were performed in electron beam facility, EBTS, ${ }^{21)}$ Sandia (US). The VPS-Be mock-ups survived under thermal fatigue loads at $1 \mathrm{MW} / \mathrm{m}^{2}$ for 1000 cycles. $^{22)}$ 


\subsection{CFC materials and the components}

For the present design of ITER, 3D carbon fibre reinforced composite (CFC) has been selected as armour for the divertor target near the plasma strike point. ${ }^{23,24)} \mathrm{CFC}$ materials have been developed with the goal to obtain high thermal conductivity ( $>300 \mathrm{~W} / \mathrm{mK}$ at RT), high density, high purity and a proper balance of the mechanical properties. Details concerning the development of CFC for fusion applications are described in Ref. 25, 26. The reference ITER candidate CFCs are Sepcarb ${ }^{\circledR}$ NB31 (Snecma Propulsion Solide (France)), Concept 2 (Dunlop Aerospace (UK)) and NIC-01 (Nisseki-Corporation (Japan)). ${ }^{7)}$ The first two materials have an average $25-30 \%$ volume fraction of high conductivity expitch fibres in the direction with the highest thermal conductivity (5-7\% of ex-PAN fibres in the other two directions). NIC-01 has a higher fibre content (43\%/18\%/6\% Granoc pitch fibres), which is responsible for its superior thermal conductivity. The densification is performed by chemical infiltration of pyrocarbon, followed by a graphitisation heat treatment. ${ }^{27)} \mathrm{NB} 31$ also exists in a silicon-doped grade, named NS31, developed to minimise the chemical erosion and the tritium uptake. ${ }^{28)} \mathrm{NS} 31$ is produced by the final infiltration of liquid silicon leading partly to the formation of silicon carbide. Parameters in terms of physical, mechanical properties or average densities of these CFC grades are listed in many publications. ${ }^{25,29-32)}$

The development of the $\mathrm{CFC} / \mathrm{Cu}$ joint was one of the most challenging $\mathrm{R} \& \mathrm{D}$ efforts. The main problem is a large mismatch of thermal expansion between CFC and $\mathrm{Cu}$ alloy heat sink. Several possible solutions are presently available. Active Metal Casting (AMC ${ }^{\circledR}$ ), developed in 1995 by Plansee (Austria) consists of casting $\mathrm{Cu}$ onto a laser textured and titanium activated CFC surface. ${ }^{7,33)}$ Beside this well established technology, several brazing methods for joining CFC to copper have been developed, mainly by JAERI (Japan $)^{29,32,34)}$ and more recently by Ansaldo Ricerche (Italy). ${ }^{28,35,36)}$

\subsection{W materials and the components}

Pure sintered $\mathrm{W}$ is currently recommended as a reference $\mathrm{W}$, which is available from different suppliers. The main drawback of $\mathrm{W}$ material is severe cracking due to thermal stress because of the brittleness below the ductile to brittle transition temperature (DBTT) at around $400^{\circ} \mathrm{C}$. Therefore, the application range of solid pure $\mathrm{W}$ is limited to temperature above the DBTT and below the recrystallization temperature at around $1300^{\circ} \mathrm{C}$. To improve the mechanical properties at low temperature, various alloys such as W5\% Re have been developed. ${ }^{37)}$ Dispersion strengthened (DS) $\mathrm{W}$, e.g. $\mathrm{W}-1 \% \mathrm{La}_{2} \mathrm{O}_{3}$ which has higher recrystallization temperature became a promising $\mathrm{W}$ material. ${ }^{37)}$ Recently, W materials produced by mechanical alloying (MA) of ultrafine grain $\mathrm{W}(\sim 1 \mu \mathrm{m})$ with $\mathrm{TiC}$ dispersion particles have been developed. Especially, the $\mathrm{W}$ material containing 0.2 mass $\%$ of $\mathrm{TiC}$ showed remarkable reduction of DBTT down to $180^{\circ} \mathrm{C}$ and increase of the recrystallization temperature above $2000^{\circ} \mathrm{C} .{ }^{38,39)}$

The main obstacle of joining $\mathrm{W}$ to $\mathrm{Cu}$ alloys is the large thermal expansion mismatch as is the case for $\mathrm{CFC} / \mathrm{Cu}$ joining. As technological solutions, castellation (flat tile
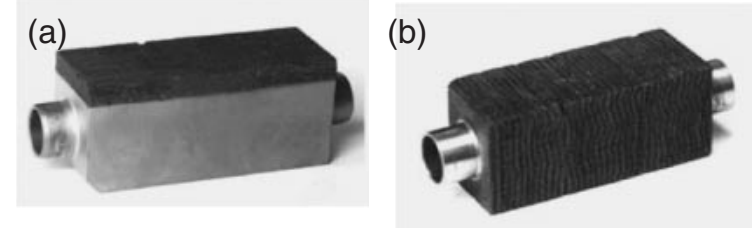

(c)

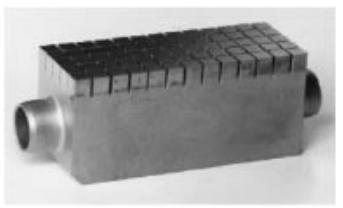

(d)

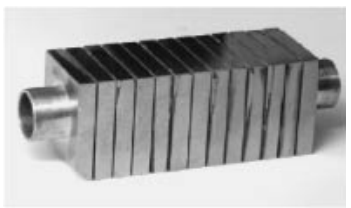

Fig. 3 Mock-up designs for ITER divertor. (a) CFC flat tile, (b) CFC monoblock, (c) W flat tile (macrobrush) and (d) W monoblock design.

design (see Fig. 3(c))) and $4 \mathrm{~mm}$ thick monolithic plates (mono-block design (see Fig. 3(d))) or even thinner plates ( $0.2 \mathrm{~mm}$ thick), lamellae structure (mono-block design) have been selected in order to reduce thermal stress under high heat fluxes. For reducing thermal stress, functionally graded materials (FGM) is also an attractive solution. Optimization of FGM layer in terms of reduction of thermal stress, have been done by finite element calculation methods (FEM) and FGM was built by VPS coating by separated $\mathrm{W}$ and $\mathrm{Cu}$ powder feedings. ${ }^{40-42)}$ For joining of solid $\mathrm{W}$ to the heat sink, common methods are casting, brazing, electron beam welding $^{7)}$ and hot pressing. ${ }^{43)}$

An alternative concept is $\mathrm{W}$ coating on heat sinks. As coating technologies, VPS ${ }^{44-48}$ and chemical vapor deposition (CVD) ${ }^{49,50)}$ have been proposed and tested in terms of the performances under high heat flux loading. Presently, VPS-W, density of more than $90 \%$ of sintered $\mathrm{W}$ has been achieved. ${ }^{45)}$ The performances were discussed under thermal fatigue tests at power density, $<10 \mathrm{MW} / \mathrm{m}^{2} 45$ ) and under plasma loadings in the ASDEX-Upgrade tokamak, $\sim 6 \mathrm{MW} /$ $\mathrm{m}^{2}{ }^{46)}$ and in TEXTOR tokamak, $\sim 20 \mathrm{MW} / \mathrm{m}^{2}{ }^{47)} \mathrm{CVD}-\mathrm{W}$ coatings have been developed on pure $\mathrm{Cu}, \mathrm{W}-30 \% \mathrm{Cu}$ or Mo substrates. ${ }^{49,50)}$ The layer has high purity and comparable thermal properties to sintered pure W. ${ }^{50}$ Thermal fatigue tests $\left(22 \mathrm{MW} / \mathrm{m}^{2}\right.$ for $\left.10 \mathrm{~s}\right)$ on CVD-W with a thickness $2 \mathrm{~mm}$ showed the excellent performances. ${ }^{49)}$ Thermal shock tests show the good resistance of CVD-W compared with sintered pure W. ${ }^{50)}$

\subsection{Non-destructive examination}

ITER design has to be consistent with nuclear technology and remote maintenance feasibility. The divertor is being designed very flexible and to be removable cassettes. Each of the 54 divertor cassettes consists of 27 outer and 21 inner vertical target units which are composed of 40 and 35 CFC monoblocks, respectively. Summing up, approximately, 100 000 CFC monoblocks will be installed in the ITER divertor. In case of $\mathrm{W}$ macro brush design, the number of the individual rods is foreseen to be in the order of half a million. ${ }^{7)}$ The first wall armored with Be tiles has been designed to be approximately 1750 large panels with a size of $1100 \mathrm{~mm} \times 350 \mathrm{~mm} .{ }^{18)}$ The manufacturing of the delicate component with a high acceptance rate is a technological 
challenge. Accordingly, non-destruction examination (NDE) is strongly demanded to guarantee the quality of the mockups. Several methods have been demonstrated for CFC and W mock-ups: ultrasonic examination, ${ }^{51-53)}$ transient thermography examination for actively cooled mock-ups by using hot and cold water loops ${ }^{51,54,55)}$ and lock-in thermography examination. ${ }^{56)}$ The lock-in thermography examination has been performed to detect defects in flat tile CFC mockups. The phase shift of periodic temperature increase at different locations was analyzed under periodic heating by 4 flash lamps $(4 \times 1 \mathrm{~kW})$. In this analysis, the frequency of periodic heating and loading power density are the important parameters. The feasibility of these examinations can be found in recent review papers. ${ }^{7,57,58)}$

\section{Static High Heat Flux Testing: Screening and Ther- mal Fatigue Tests}

During routine operation cycles in ITER, the PFCs are subjected to high heat fluxes as mentioned in Section 1. To simulate such heat load condition, various heat sources are used. The tests are performed with surface loading on actively cooled mock-ups with defined power densities. There are two kinds of testing schemes: screening tests and thermal fatigue tests. Screening tests are performed by stepwisely increased heat fluxes. It reveals the heat removal capability of various mock-up geometries. Thermal fatigue tests are performed by a cyclic high heat flux up to typically several thousands cycles. Each cycle consists of a heating and a cooling phase. The duration of the heating phase is typically 10 to 30 seconds, depending on the time period until thermal equilibrium is achieved. The test reveals thermal fatigue performance of the mock-ups. During these tests, failure in the mock-ups are directly observed by overheating of surfaces due to reduction of thermal contact above the tolerable heat fluxes for the mock-ups. Figure 4 illustrates summary of thermal fatigue tests on various CFC mock-ups.

The main in-situ evaluations are done by observation of surface and bulk temperatures at each power density and each cycle. The surface temperature is observed by optical thermometers, e.g. infrared (IR) scanners, single color and two color pyrometers. Especially IR scanners represent

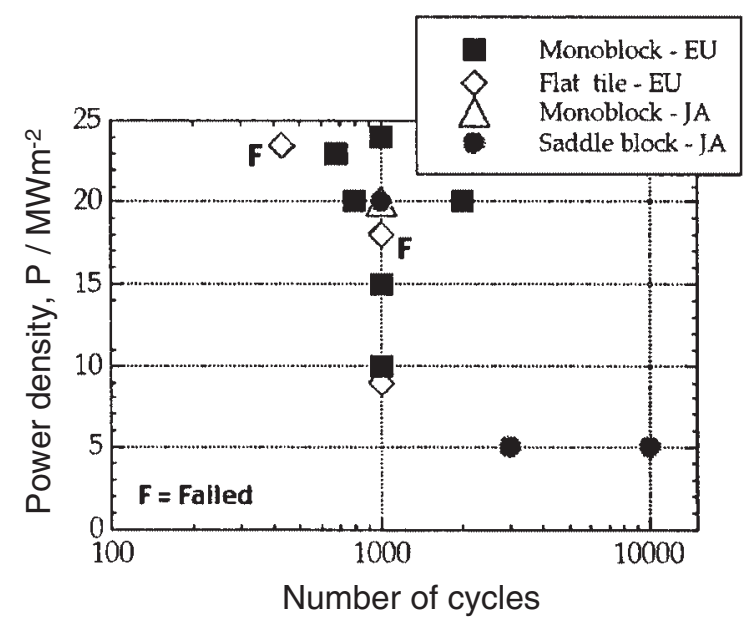

Fig. 4 Summary of thermal fatigue tests on various CFC designs. ${ }^{5)}$ powerful diagnostics because they provide two dimensional temperature distribution on the surface, whereas, pyrometers measure temperatures in the observing spots. The critical point of the measurements by means of IR scanner and single-color pyrometer are the fact that users have to define an emissivity which is dependent on many parameters, e.g. type of material, surface morphology, observation angles and the detecting wavelength. The emissivity is calibrated by comparing between surface temperature by optical thermometers and the bulk temperature by thermocouples at the thermal equilibrium. In this point, two-color pyrometer has a great advantage on measurement of absolute surface temperature without setting an emissivity, although it has normally rather high threshold of measurable minimum temperature. The bulk temperature is measured by embedded thermocouples in mock-ups. This is a reliable and direct measurement. However, the measurement is sometime disturbed by poor thermal contact of the thermocouples to mock-ups, which causes underestimation of the bulk temperature. And positioning of the thermocouples should be carefully done. The mis-positioning of thermocouples results in a large deviation of the measured temperatures because of a large temperature gradient in mock-ups.

Table 1 shows various heat sources and the the parameters. All these facilities are needed to provide enough test capacity for R\&D of ITER components. Consequently, it is very important to address the correlation of the evaluated results from different facilities since all of them have different machine parameters. To access the correlation between the results from different facilities, Round Robin Tests have been done by JUDITH, JEBIS, FE200, EBTS, TSEFFY and JET NBI Testbed ${ }^{59,60)}$ with the same nominal power density on the same mock-ups in those facilities. The main conclusion from these tests is that the surface temperatures evolution with power densities, fairly agreed with each other, although there were systematic deviation. The detailed discussion on the deviation can be found in references. ${ }^{59,60)}$

The crucial points are (1) surface temperature measurement and (2) power density calibration. Calibration of surface temperature should have been done at each facility because of the different specification and alignment of optical thermometers (detecting wavelength, angle and window materials). The power density is calibrated most commonly by water calorimetry. ${ }^{61)}$ Power density is estimated by measuring the temperature difference between inlet and outlet coolant. The absorbed power density is calculated by the following equation,

$$
P_{\mathrm{abs}}=C_{\mathrm{p}} \Delta T \phi
$$

where $C_{\mathrm{p}}$ is the specific heat, $\Delta T$ the temperature increase, and $\phi$ the mass flow of the coolant. Temperature measuring points of the coolant water is needed to be as close as possible to the mock-up since heat transfers from coolant to the coolant tube and the other parts having thermal contacts. Bulk material calorimeters made of thermally isolated graphite and Be coupons have also been applied using the specific heat, temperature increase and mass of the bulk materials. ${ }^{62)}$ The incident current was also used to calibrate power density by the following equation in case of electron beam facilities. ${ }^{61)}$ 
Table 1 Machine parameters of various heat sources.

\begin{tabular}{|c|c|c|c|c|c|c|c|c|c|}
\hline $\begin{array}{c}\text { Heat } \\
\text { source }\end{array}$ & Facility & $\begin{array}{c}\text { Power, } \\
{[\mathrm{kW}]}\end{array}$ & $\begin{array}{l}\text { Max. Power } \\
\text { density, } \\
{\left[\mathrm{GW} / \mathrm{m}^{2}\right]}\end{array}$ & $\begin{array}{l}\text { Pulse } \\
\text { duration, } \\
{[\mathrm{s}]}\end{array}$ & $\begin{array}{l}\text { Max. } \\
\text { Loaded area, } \\
{\left[\mathrm{m}^{2}\right]}\end{array}$ & $\begin{array}{l}\text { Impact } \\
\text { energy, } \\
{[\mathrm{keV}]}\end{array}$ & $\begin{array}{c}\text { Remarks } \\
\text { Be: Be sample, irr: irradiated sample }\end{array}$ & $\begin{array}{l}\text { Institute, } \\
\text { country }\end{array}$ & Ref. \\
\hline $\begin{array}{l}\text { Electron } \\
\text { beam }\end{array}$ & JUDITH & 60 & 15 & $0.001-\mathrm{CW}$ & 0.01 & $150(\mathrm{e})$ & $\begin{aligned} \text { Be, irr; Beam }(\phi= & 1 \ldots 2 \mathrm{~mm}) \text { scanned by }<100 \mathrm{kHz} \text {, Coolant loop: } \\
& \text { water, RT, }<8 \mathrm{~m} / \mathrm{s},<3 \mathrm{MPa}\end{aligned}$ & FZ Juelich, DE & 63) \\
\hline $\begin{array}{l}\text { Electron } \\
\text { beam }\end{array}$ & JEBIS & 400 & 2 & $0.0001-\mathrm{CW}$ & 0.18 & $100(\mathrm{e})$ & Beam $(\phi=1 \ldots 2 \mathrm{~mm})$ scanned by $<1 \mathrm{kHz}$, Coolant loop: water, RT, $<51 / \mathrm{s},<4 \mathrm{MPa}$ & JAERI, JP & 64) \\
\hline $\begin{array}{l}\text { Electron } \\
\text { beam }\end{array}$ & OHBIS* & 50 & 1 & $0.001-\mathrm{CW}$ & $6.25 \times 10^{-4}$ & $30(\mathrm{e})$ & Be, irr, Beam $(\phi=5 \mathrm{~mm})$ scanned by $<1 \mathrm{kHz}$, Coolant loop: water, RT, $<1.71 / \mathrm{s},<2 \mathrm{MPa}$ & JAERI, JP & 62) \\
\hline $\begin{array}{l}\text { Electron } \\
\text { beam }\end{array}$ & FE200 & 200 & 60 & $0.001-6000$ & 1 & $200(\mathrm{e})$ & $\begin{aligned} \text { Beam }(\phi= & 2 \ldots 10 \mathrm{~mm}) \text { scanned by }<14 \mathrm{kHz} \text {, coolant loop: } \\
& \text { water, } 50-230^{\circ} \mathrm{C},<61 / \mathrm{s},<3.3 \mathrm{MPa}\end{aligned}$ & $\begin{array}{l}\text { CEA Le Cresout, } \\
\text { FR }\end{array}$ & 67) \\
\hline $\begin{array}{l}\text { Electron } \\
\text { beam }\end{array}$ & EB1200 & 1200 & 10.6 & $0.0005-\mathrm{CW}$ & 0.27 & $40(\mathrm{e})$ & Beam $(\phi=2 \ldots 12 \mathrm{~mm})$ scanned by $<10 \mathrm{kHz}$, coolant loop: water, $20-280^{\circ} \mathrm{C},<32 \mathrm{l} / \mathrm{s},<7 \mathrm{MPa}$ & Sandia, US & 21) \\
\hline $\begin{array}{l}\text { Electron } \\
\text { beam }\end{array}$ & EBTS & 30 & 9.5 & $0.002-\mathrm{CW}$ & 0.01 & $30(\mathrm{e})$ & 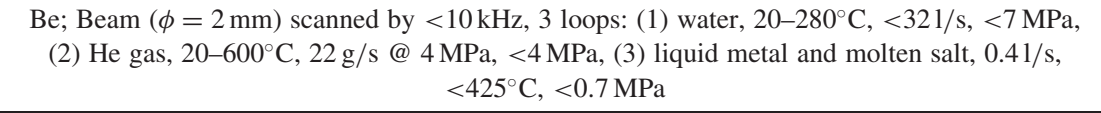 & Sandia, US & 21) \\
\hline $\begin{array}{c}\text { Electron } \\
\text { beam }\end{array}$ & TSEFFY & 60 & 0.2 & $0.01-\mathrm{CW}$ & 0.25 & $30(\mathrm{e})$ & $\begin{array}{c}\text { Be; Beam }(\phi=20 \mathrm{~mm}) \text { scanned by } 0.5(\mathrm{x}) \text { and } 0.2(\mathrm{y}) \mathrm{kHz} \text {, coolant loop: } \\
\text { water, }<90^{\circ} \mathrm{C}, 31 / \mathrm{s},<2 \mathrm{MPa}\end{array}$ & Efremov inst. RF & 15) \\
\hline $\begin{array}{c}\text { Electron } \\
\text { beam }\end{array}$ & ACT & 50 & 1 & $\mathrm{CW}$ & 0.04 & $30(\mathrm{e})$ & Beam $(\phi=8 \mathrm{~mm})$ scanned by $0.2 \mathrm{kHz}$, coolant loop: water, RT, $12 \mathrm{~m} / \mathrm{s},<0.5 \mathrm{MPa}$ & NIFS, JP & 65) \\
\hline $\begin{array}{c}\text { Electron } \\
\text { beam }\end{array}$ & Electron beam & 60 & 3 & $0.3-\mathrm{CW}$ & $2.5 \times 10^{-5}$ & $60(\mathrm{e})$ & Beam $(\phi=5 \ldots 25 \mathrm{~mm})$, coolant loop: water, RT, $0.11 / \mathrm{s},<4 \mathrm{MPa}$ & SWIP, CN & 68) \\
\hline $\begin{array}{l}\text { Electron } \\
\text { beam }\end{array}$ & EBTH & 3 & 0.35 & $0.1-\mathrm{CW}$ & $5 \times 10^{-5}$ & $20(\mathrm{e})$ & Beam $(\phi=1 \ldots 20 \mathrm{~mm})$ scanned by $10 \mathrm{kHz}$, coolant loop: water, RT & Kyushu Univ., JP & 66) \\
\hline $\begin{array}{c}\text { Particle } \\
\text { beam }\end{array}$ & PBEF & 1500 & $60 / 10$ & $0.01-1000$ & 0.1 & $\begin{array}{c}50 \\
(\mathrm{H}, \mathrm{He}) \\
\end{array}$ & 2 ion sources, $\left(\phi=150 \mathrm{~mm}\right.$ and $\left.100 \times 1000 \mathrm{~mm}^{2}\right) 2$ coolant loops: water, RT, $30001 / \mathrm{s}, 2 \mathrm{MPa}$ & JAERI, JP & 77) \\
\hline $\begin{array}{c}\text { Particle } \\
\text { beam }\end{array}$ & JET NBTB & 7500 & 0.25 & $0.005-20$ & 0.08 & $130(\mathrm{D})$ & Be, Tritium; coolant loop: water, RT, 101/s, $<1 \mathrm{MPa}$ & JET, UK & 83) \\
\hline IR heater & FIWATKA** & 500 & $8 \times 10^{-4}$ & $30-\mathrm{CW}$ & $0.25 \times 0.6$ & Infrared & Coolant loop: water, $221 / \mathrm{s}, 1.6 \mathrm{MPa}, \mathrm{RT}-120^{\circ} \mathrm{C}$ & $\begin{array}{c}\text { FZ Karlsruhe, } \\
\text { DE }\end{array}$ & 84) \\
\hline IR heater & $\begin{array}{c}\text { CEF 1-2 } \\
\text { EDA-BETA }\end{array}$ & 100 & $8 \times 10^{-4}$ & $\sim 300$ & $<0.11 \times 0.08$ & Infrared & Be; coolant loop: water, $\mathrm{RT}-140^{\circ} \mathrm{C}$ & Brasimone, IT & 89) \\
\hline $\begin{array}{l}\text { Plasma } \\
\text { gun }\end{array}$ & MK200UG & $10^{6}$ & 300 & $5 \times 10^{-5}$ & $<3.9 \times 10^{-5}$ & $\begin{array}{c}1-3 \\
\text { (ion) } \\
\end{array}$ & Hydrogen plasma $(\phi=60 \ldots 70 \mathrm{~mm}), \mathrm{B}=2-3 \mathrm{~T}$ & TRINIRI, RF & 120) \\
\hline $\begin{array}{l}\text { Plasma } \\
\text { gun }\end{array}$ & QSPA-T & $3.5 \times 10^{-5}$ & 125 & $2-5 \times 10^{-4}$ & $<2.8 \times 10^{5}$ & $\begin{array}{c}0.1 \\
\text { (ion) }\end{array}$ & Hydrogen plasma $(\phi=40 \ldots 60 \mathrm{~mm})$ & TRINIRI, RF & 123) \\
\hline
\end{tabular}

CW: continuous work, ${ }^{*}$ shut down in $2003,{ }^{* *}$ presently out of service 


$$
P_{\text {abs }}=P_{\text {inc }} \alpha=U I \alpha
$$

where $U$ is the acceleration voltage, $I$ the beam current and $\alpha$ the absorption coefficient (for $\mathrm{W}, \alpha_{\mathrm{W}}=55 \%$ for an acceleration voltage of $120 \mathrm{keV})$.

\subsection{Static heat load testing by electron beam}

Advantages of high heat flux testing by electron beam are the flexible operation (pulse length, $\sim 1 \mathrm{~ms}$ up to continuous work) and homogeneous heat loading on large areas. A number of electron beam facilities have been constructed, JUDITH $^{63)}$ in Forschungszentrum Juelich (Germany), JEBIS, ${ }^{64)}$ OHBIS $^{62)}$ in JAERI, ACT ${ }^{65)}$ in NIFS, EBHT ${ }^{66)}$ in Kyushu University (Japan), FE20067) in CEA (France), TSEFFY $^{15)}$ in Efremov Institute (Russia), EBTS, EB120021) in Sandia (USA), and an electron beam facility in SWIP (China). ${ }^{68)}$ In this paper, recent results of ITER relevant high heat flux testing performed by three of those electron beam facilities, JUDITH, JEBIS and OHBIS are mainly summarized.

JUDITH (JUelicher DIvertor Test facility in Hot cells) has focused its test programe mainly on mock-ups designed by EFDA (European Fusion Development Agreement). Since JUDITH is installed in hot cells, it has a great advantage to perform high heat flux testing on irradiated and toxic samples such as Be samples. CFC flat tile and monoblock design (see Figs. 3(a) and (b)) have been tested in JUDITH before and after neutron irradiation. Both mock-ups were produced by the AMC joining technique with NB31 armor. In the unirradiated stage both types of mock-ups showed very high failure limits. ${ }^{69-74)}$ The flat tile mock-up survived 1000 cycles at $20 \mathrm{MW} / \mathrm{m}^{2}$. The monoblock was loaded for 1000 cycles at $19 \mathrm{MW} / \mathrm{m}^{2}{ }^{74)}$ After neutron irradiation $(0.2,0.35,1 \mathrm{dpa}$ at $\sim 200^{\circ} \mathrm{C}, 350^{\circ} \mathrm{C}$ and $700^{\circ} \mathrm{C}$ in HFR, Petten, the Nederland), both types of CFC mock-ups showed a dramatic increase of surface temperature due to the reduction of thermal conductivity of CFC. ${ }^{74)}$ In case of CFC flat tiles, detachment of a tile started after 200 cycles at $19.5 \mathrm{MW} / \mathrm{m}^{2}$ after $0.2 \mathrm{dpa}$ at $200^{\circ} \mathrm{C}$, and tests were limited to $15 \mathrm{MW} / \mathrm{m}^{2}$ after $1 \mathrm{dpa}$ at $200^{\circ} \mathrm{C}$ because of strong erosion (sublimation). Monoblock design is considered more robust because it will not detach due to the geometry, however, monoblock mock-up showed even more severe temperature increase after irradiation. The maximum surface temperature of the monoblock mock-up increased from 401 to $1580^{\circ} \mathrm{C}$ at a relatively moderate power density of $5 \mathrm{MW} / \mathrm{m}^{2}$ after $0.2 \mathrm{dpa}$ at $200^{\circ} \mathrm{C}$ (surface temperature of flat tile increased from $155^{\circ} \mathrm{C}$ to $290^{\circ} \mathrm{C}$ after $0.2 \mathrm{dpa}$ at $200^{\circ} \mathrm{C}$, and $155^{\circ} \mathrm{C}$ to $550^{\circ} \mathrm{C}$ after $1 \mathrm{dpa}$ at $200^{\circ} \mathrm{C}$ ). In case of CFC monoblock mock-ups, overheating (>2000 $2500^{\circ} \mathrm{C}$ ) of the surfaces which caused strong sublimation occurred at $14 \mathrm{MW} / \mathrm{m}^{2}$ for $0.2 \mathrm{dpa}$ at $200^{\circ} \mathrm{C}, 12 \mathrm{MW} / \mathrm{m}^{2}$ for $0.35 \mathrm{dpa}$ at $350^{\circ} \mathrm{C}, 16 \mathrm{MW} / \mathrm{m}^{2}$ for $0.35 \mathrm{dpa}$ at $700^{\circ} \mathrm{C}^{70,71,74)}$ Figure 5 shows the surface temperature as a function of power density for un-irradiated and neutron irradiated CFC monoblock mock-ups. ${ }^{71)}$ The thermal fatigue tests of the monoblock mock-up $\left(0.2 \mathrm{dpa}\right.$ at $\left.200^{\circ} \mathrm{C}\right)$ were carried out at $12 \mathrm{MW} / \mathrm{m}^{2}$ for 1000 cycles without failure. ${ }^{74)}$ This was again limited by overheating. During thermal fatigue tests, all mock-ups showed annealing effects: slight decreases of surface temperature. ${ }^{70,73,74)}$ Nevertheless, overheating after

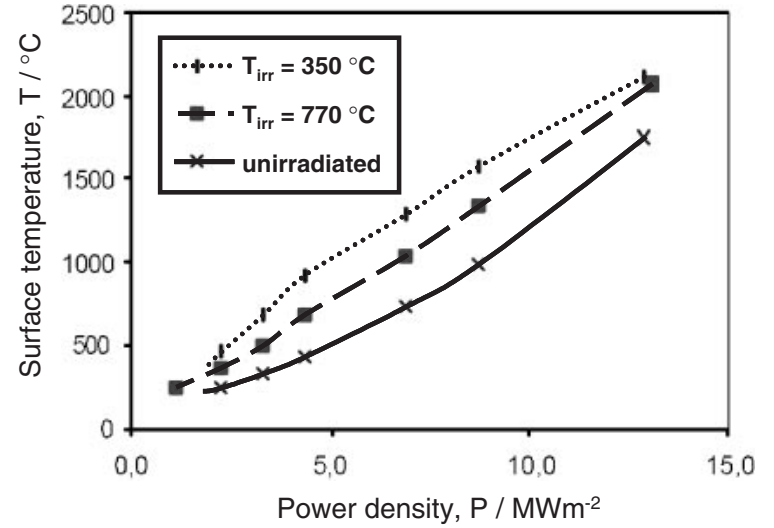

Fig. 5 High heat flux performances of un-irradiated and neutron irradiated $\mathrm{CFC}$ monoblock mock-ups. Material irradiated to $0.3 \mathrm{dpa}$ at $350^{\circ} \mathrm{C}$ and $770^{\circ} \mathrm{C}^{58)}$

neutron irradiation indicates a limiting factor for the use of CFC mock-ups in a neutron irradiation environment, especially for the machines beyond ITER.

W flat tile (macrobrush) and monoblock design (see Figs. 3(c) and (d)) have been tested. In the un-irradiated stage, $\mathrm{W}\left(\mathrm{W}-1 \% \mathrm{La}_{2} \mathrm{O}_{3}\right)$ macrobrush mock-up did not show any indication of failure after 1000 cycles at $14 \mathrm{MW} / \mathrm{m}^{2}{ }^{6}{ }^{61,70)}$ However, the failure limits are reduced to about $10 \mathrm{MW} / \mathrm{m}^{2}$ after 0.15 and $0.6 \mathrm{dpa}$ at $200^{\circ} \mathrm{C}$. The failure was caused by detachment of the $\mathrm{W}$ rods at the joining between $\mathrm{W}$ alloy and OFHC-Cu which is ascribed to radiation induced embrittlement of the OFHC-Cu layer. ${ }^{74)}$ On the other hand, W monoblock showed rather benign performance before and after irradiation at $18 \mathrm{MW} / \mathrm{m}^{2}$ for 1000 cycles. ${ }^{74)} \mathrm{W}$-coated mock-up, VPS-W (5 mm thickness) on CuCrZr with Ni-Al-Si interlayer, was tested as an alternative solution of $\mathrm{W}$ components. The thermal fatigue tests were limited to $7.6 \mathrm{MW} / \mathrm{m}^{2}$ due to successive increase of the surface temperature. Metallographic inspection showed that large cracks formed parallel to the loaded surface. ${ }^{72}$ VPS-W appears to be an option only for the lower power density area. According to the results, $\mathrm{W}$ monoblock design is the most promising option for future fusion devices.

Three small scale Be mock-ups $\left(15 \times 25 \mathrm{~mm}^{2}, 3\right.$ and $8 \mathrm{~mm}$ thickness) manufactured in different brazing conditions were tested in JUDITH before and after irradiation. ${ }^{70)}$ All mockups withstood more than $6.5 \mathrm{MW} / \mathrm{m}^{2}$ for 1000 cycles even after neutron irradiation of $0.35 \mathrm{dpa}$ at $350^{\circ} \mathrm{C}$. Scale-up of mock-ups is the technological challenge and it is strongly required for Be mock-ups. As the first step, medium-scale Be mock-ups (approximately $100 \times 100 \mathrm{~mm}^{2}$ ) manufactured by different HIP and brazing condition and examined. ${ }^{14)}$ The all brazed mock-ups failed at $3 \mathrm{MW} / \mathrm{m}^{2}$. It is far beyond the ITER requirement for the first wall $\left(\sim 0.5 \mathrm{MW} / \mathrm{m}^{2}\right)$, nevertheless, it is still needed to develop reliable joining techniques of Be armor to heat sink in large scale mock-ups.

JEBIS (JAERI Electron Beam Irradiation Stand) in JAERI (Japan) is being used to carried out thermal cycles tests of small- and medium-scale divertor mock-ups with 2D-CFC (CX-2002U) and W armor tiles joined to Cu-alloy heat sink for ITER as well as high performance cooling tubes. As a castellation structure, rod-shaped W armors were tested. 
Cyclic heat load tests on small-scale mock-ups at $10 \mathrm{MW} / \mathrm{m}^{2}$ in JEBIS showed no failure over 3000 cycles, and applicability of this option has been demonstrated. ${ }^{75)}$ Besides, R\&D of armor design and joining development, improvement of the heat removable capability is another essential approach. As for the thermal fatigue tests on high performance cooling tubes, the screw tube made of $\mathrm{CuCrZr}$ with threading was tested at heat fluxes above $20 \mathrm{MW} / \mathrm{m}^{2}{ }^{26}$ ) This is a copper cooling tube $(\phi=10 \mathrm{~mm})$ with internal fins in a helical and triangular shape machined by simple mechanical threading (M10). Heat removal capabilities have already been confirmed, comparable with those of the twisted tape (swirl tube). ${ }^{77)}$ Metallographic observation showed fatigue-cracks initiated from the outer surface of the tube and propagated towards the inner surface. Although stress concentration and crack initiation at the root of the internal fins were concerned in this concept, the results indicated that the fins had no dominant effect on their fatigue lifetimes.

OHBIS (Oarai Hot-cell electron Beam Irradiating System) ${ }^{62)}$ in JAERI, is used to analyze mock-ups with Be as well as neutron-irradiated mock-ups with CFC armor tiles. ${ }^{78)}$ Small scale Be mock-ups (Be tiles: $15 \times 20 \mathrm{~mm}^{2}$ ) have been tested at a heat flux of $5 \mathrm{MW} / \mathrm{m}^{2}$ for 1000 cycles. ${ }^{12)}$ In these mock-ups, Be tiles are bonded to DS-Cu heat sink with an interlayer of either $\mathrm{Al} / \mathrm{Ti} / \mathrm{Cu}$ or pure $\mathrm{Cu}$ by HIP. To investigate the neutron irradiation effects on PFCs with CFC tiles joined to DS-Cu heat sinks, high heat load tests of small-scale mockups were also carried out in OHBIS. Neutron fluences to these mock-ups were 0.3 and 0.4 dpa at $300^{\circ} \mathrm{C}$ irradiated in JMTR (Japan Material Testing Reactor) in JAERI. No damage was observed in the mock-ups throughout 1000 thermal cycles at $5 \mathrm{MW} / \mathrm{m}^{2}$. Again, significant increase of surface temperatures of the CFC tiles after neutron-irradiation was observed due to reduction of thermal conductivity of the CFC.

FE200 in CEA (France), has a large vacuum chamber which enables to perform heat load testing on large scale mock-ups. Divertor vertical target medium scale $(40 \mathrm{~mm} \times$ $500 \mathrm{~mm}$ ) prototype with $\mathrm{W}$ and CFC targets was manufactured. The mock-up consists of $\mathrm{W}$ (pure $\mathrm{W}$ and $\mathrm{W}-1 \% \mathrm{La}_{2} \mathrm{O}_{3}$ ) macro brush armor on DS-Cu heat sink and CFC (NB31) monoblock armors with DS-Cu cooling tube integrated on a SS316L steel back plate. The details of manufacturing can be found in. ${ }^{79)}$ It was tested in FE200 up to $15 \mathrm{MW} / \mathrm{m}^{2}$ at the $\mathrm{W}$ target and $20 \mathrm{MW} / \mathrm{m}^{2}$ at the CFC target for 1000 cycles. After the completion of the high heat flux test, there were no appreciable differences between pure $\mathrm{W}$ and $\mathrm{W}-1 \% \mathrm{La}_{2} \mathrm{O}_{3}$ as far as the thermal fatigue behavior was found. The detachment of the two $\mathrm{W}$ tiles after additional 100 cycles at $15 \mathrm{MW} / \mathrm{m}^{2}$ seems to be due to creep damage of the pure copper interlayer and concerned only the area with a coarse castellation. No indication of failure was found in the CFC parts. ${ }^{79)}$

\subsection{Static heat load testing by other heat sources}

\subsubsection{Static heat loads by particle beam facilities}

PBEF (Particle Beam Engineering Facility) in JAERI can generate an intense hydrogen ion beam up to $1.5 \mathrm{MW}$ for a duration of 0.01 to $1000 \mathrm{~s}$. One of the advantages of the usage of the hydrogen ion beam as a heat source is the lower reflection at metal targets than electron beam. In particular, it is suitable to heat up different target materials simultaneously, such as the mock-ups with CFC and W surfaces. PBEF has a large vacuum chamber $(3.5 \mathrm{~m}$ wide, $7 \mathrm{~m}$ long and $4 \mathrm{~m}$ high), in which a full-size divertor cassette can be tested. Two ion beam sources can be adapted each other to experimental conditions: One is a small ion source that can generate Gaussian beam profiles with a FWHM of $140-160 \mathrm{~mm}$ and its peak value ranges up to $60 \mathrm{MW} / \mathrm{m}^{2}$. Another one is a large ion source that can deliver sheet-like hydrogen ion beams (loading area of $0.1 \mathrm{~m} \times 1 \mathrm{~m}$ at the maximum heat flux of $10 \mathrm{MW} / \mathrm{m}^{2}$ ) onto mock-ups. Many kinds of high heat flux tests have been carried out including critical heat flux (CHF) test on cooling tubes with various geometry and thermal fatigue tests on large- or full-scale divertor mock-ups in PBEF.

Heat removal capabilities of high performance cooling tubes with pressurized water have been investigated including rectangular tubes with internal saw-toothed fins $^{80)}$ and annular tubes with internal twisted fins. ${ }^{81)}$ A promising cooling tube for high heat flux components is a screw tube. It was found that the screw tube made of pure $\mathrm{Cu}$ with M10 threading could remove as high heat flux as $45 \mathrm{MW} / \mathrm{m}^{2}$ with water flowing at the pressure of $1 \mathrm{MPa}$ and at room temperature.

To examine synergistic effect of helium (He) bombardment and heat loads, heat load experiments with He particle beam was performed. As a result, the loaded samples showed noticeable microstructure changes on the surface, i.e. blistering and exfoliation in particular conditions. ${ }^{82)}$ The results indicate that $\mathrm{W}$ surfaces modified remarkably by synergistic effect of heat and He particle loads which are similar to the loads in ITER: heat loads and He ash (one of the fusion products).

In the JET Neutral Beam Injector (NBI) testbed ${ }^{83)}$ in UKAEA (UK), the power loading is performed by ion beam with the composition: $56 \% \mathrm{H}^{+}, 6 \% \mathrm{H}_{2}{ }^{+}, 38 \% \mathrm{H}_{3}{ }^{+}$. The acceleration energy was up to $56 \mathrm{keV}$, and the beam profile is Gaussian. Maximum power density is $100 \mathrm{MW} / \mathrm{m}^{2}$. Active cooling is performed with water at room temperature with a flow rate of $601 / \mathrm{min}$. Due to the lay-out of the power supply, shots of maximum 20 seconds are available. The well calibrated power density of neutral beam injector was used as reference power density in Round Robin Test. ${ }^{60)}$

\subsubsection{Static heat loads by Infrared heater}

The majority of first wall test facilities employ IR-heaters (graphite or lamps) for realising heat fluxes onto the components for first wall application. Graphite heaters are used in the FIWATKA facility ${ }^{84)}$ in Karlsruhe (Germany) and in the CEF 1-2 thermal hydraulic facility in Brasimone (Italy). Both facilities can achieve a heat load of $0.8 \mathrm{MW} /$ $\mathrm{m}^{2},{ }^{85)}$ whereas, this value represents the absorbed heat load in the FIWATKA facility (water calorimetry) and the incident heat load at CEF $1-2 .{ }^{86)}$ For temperature and stress evaluation FE-calculations are performed because the possibility of direct diagnostics is not given. In the CEF 1-2 facility the mock-ups are properly assembled on frames and hosted in two special glove boxes (EDA-BETA and THESIS) provided with the piping, electrical feed-through, the inert gas and vacuum system and the Be particle filtering. It operates with a 
special CFC radiative electrical resistor, placed between a pair of mock-ups. In EDA-BETA, two pairs of medium size mock-ups can be tested in parallel, while THESIS offers the opportunity to simulate heat fluxes on a pair of full scale first wall panels. The surface temperature of the resistor is measured by We-Re thermocouples and monitored by a pyrometer. The Be tiles are layered with a ceramic-based, black pigmented, high emissivity paint. The inlet cooling water temperature can be switched between $20^{\circ} \mathrm{C}$ and $140^{\circ} \mathrm{C}$ to magnify thermal stresses. ${ }^{87)}$ First test campaigns in EDABETA have shown, that this stress magnification can significantly reduce the life of first wall mock-ups, even for lower incident heat fluxes between 0.3 and $0.5 \mathrm{MW} / \mathrm{m}^{2}{ }^{88)} \mathrm{In}$ the last test campaign for EDA mock-ups with Gildcop A125 have been successfully subjected to 8000 cycles of $>0.6 \mathrm{MW} / \mathrm{m}^{2}$. THESIS is presently preparing for the testing of two full scale panels, manufactured by CEA Grenoble and FRAMATOME (France). ${ }^{89)}$ The FIWATKA device consists of a large water cooled vacuum vessel. Inside a graphite heater with a surface area of $0.6 \times 0.4 \mathrm{~m}^{2}$, allowing tests on full scale mock-ups. An independent water cooling circuit with adjustable inlet temperature (RT-120 $\mathrm{C}$ ) are installed. ${ }^{90)}$ The heater is surrounded with water cooled copper shields, which have an adjustable aperture for the size of the mockups. FIWATKA was used to better simulate the thermal stress distribution, calculated for the ITER first wall during normal operation. Indeed, the massive shield block of full size components is still hot when the first wall rapidly cools down which causes stress excursion. This was simulated by inserting electric heaters in small scale first wall mock-ups in order to keep the SS rear plate hotter during cooling down. Thermal cycling at a heat flux of $0.75 \mathrm{MW} / \mathrm{m}^{2}$ for a cycle duration of 8000 cycles revealed no evidence of defects. ${ }^{91)}$ Beside ITER relevant simulations FIWATKA has been used up to July 2004 to test PFCs for a Stellerator, Wendelstein 7$\mathrm{X}$ in Greifswald (Germany). ${ }^{86)}$ The facility is presently out of service, but remains operable. ${ }^{84)}$

\subsubsection{In-pile testing: synergistic effect of neutron irra- diation and thermal fatigue loads}

A synergistic effect of neutron and cyclic thermal loads on actively cooled components is realised by in-pile thermal fatigue tests. ${ }^{92)}$ Such tests with high correspondence to real PFC operational conditions are achieved in the SM-2 experimental fission reactor at Dimitrovgrad (Russia). ${ }^{93)}$ Different attempts to create additional heat load (to neutron flux and $\gamma$ radiation heating) onto mock-up surface inside the narrow reactor channels have been made (Fig. 6). Initially a heat flux of $4-6 \mathrm{MW} / \mathrm{m}^{2}$ was reachable. ${ }^{94)}$ To increase the thermal load, massive $\mathrm{W}$ or Ta blocks, heated up by neutron and $\gamma$-ray fluxes to temperatures around $2300^{\circ} \mathrm{C}\left(1950^{\circ} \mathrm{C}\right.$ for Ta), ${ }^{95)}$ were individually fixed mechanically on each tile of the mock-ups. A soft carbon-based contacting interlayer enhanced the heat transfer to the surface of the module. This method allowed heat fluxes in the order of $8-10 \mathrm{MW} / \mathrm{m}^{2}$. Cooling of the samples is performed by water from the reactor tank. Cycling of thermal and neutron loads is provided by simple periodical pulling of the rig from the high heat flux region of the reactor. Power meters equipped with thermo couples are installed in a line next to the tested mock-up. From these measurements and additional calcu-

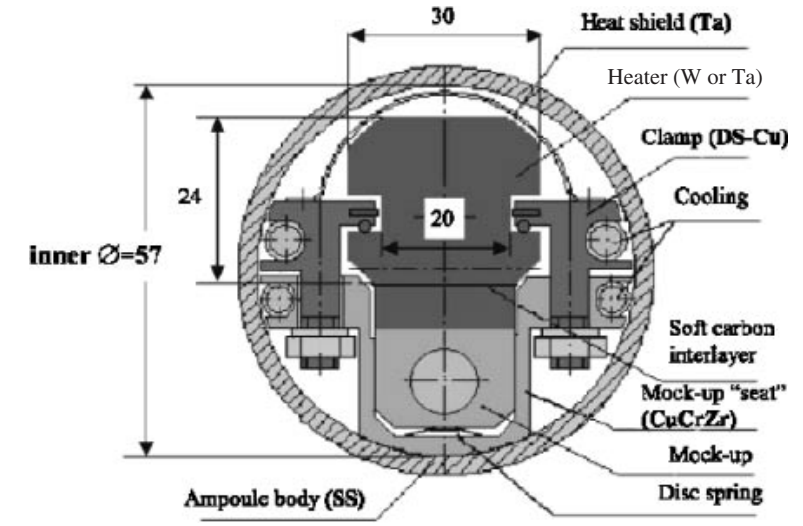

Fig. 6 Cross section of the test rig of in-pile tests in the SM-2 experimental reactor in Dimitrovgrad (Russia). ${ }^{73}$

lations by FEM the heat flux is estimated. However, direct measurements of the temperature evolution over the cycle number are not given. Thus post mortem inspection by hot metallography have been performed to obtain information on any degradation effects. The facility is mainly used to perform tests on components designed for first wall application. Different modules of ITER relevance $(\mathrm{CFC} / \mathrm{Cu}$ flat tile and monoblock, $\mathrm{Be} / \mathrm{Cu}$ ) that have been tested up to 1000 cycles and $\sim 0.2 \mathrm{dpa}$ at power densities of $7.5-8 \mathrm{MW} / \mathrm{m}^{2}$. All mock-ups showed good performances so far. ${ }^{92)}$

\section{Transient Heat Load Testing: Thermal Shock Tests}

Transient heat loads such as plasma disruption and VDE are predicted in ITER. The number of disruption and VDEs are predicted to be approximately several hundreds and some tens of shots in the component life time, respectively. ${ }^{96)}$ Although the numbers of these events are small compared with that of normal cyclic operation, these transient events could damage and erode the plasma facing surfaces considerably because of the high power densities. The other transient heat loads, type-I ELMs (Edge localized modes) will deposit non-negligible amount of energy during each event in a sub-millisecond time scale. It is essential to note that ELMs deposit energy in a frequency of around $1 \mathrm{~Hz}$ in ITER. It means that these events occur more than one million times in the ITER component lifetime. They may represent a major limitation for the divertor target lifetime of PFCs in ITER. Studies on ITER relevant ELM-like heat load testing have just started. ${ }^{97,98)}$ In this section, studies on material behavior due to disruption-like transient heat loads are mainly summarized.

Thermal shock tests have been performed up to several $\mathrm{GW} / \mathrm{m}^{2}$ or even more for very short duration. Conventional IR scanners are too slow to observe time evolution of the surface temperature. Therefore, fast diagnostics are required for these short pulse experiments. Fast pyrometers allow to measuring a fast time evolution of temperature up to the melting points (emissivity of melted surface are different from the solid metal and mostly unknown). During the experiments, the targets are surrounded by a number of fast optical diagnostics, e.g. pyrometers, photodiodes, laser scattering diagnostics and emission spectrometer (visible 
and VUV) ${ }^{99-101)}$ as well as collector probes for collecting the erosion products. ${ }^{102-104)}$ Post mortem analysis of loaded surfaces and ejected particles have been carried out. In the evaluation, the loaded surface, crater depth, features of cracking and weight loss as a function of loaded power densities are key parameters. In analysis of erosion products, the particle size distribution is important parameter.

Table 1 includes some of the test facilities which have performed thermal shock tests. Since direct comparison of experimental results from different heat sources and facilities is not straightforward, numerical modeling of material responses taking into account the machine parameters of each facility is indispensable. Numerical modeling would provide the quantitative prediction of the material behavior in ITER.

\subsection{Transient heat load testing in electron beam facili- ties}

Simulation of transient heat load testing has been carried out in electron beam facilities, JUDITH, JEBIS and OHBIS by using capacitor modes, i.e. short pulse modes. The maximum loading power densities in JUDITH, JEBIS and OHBIS are $15 \mathrm{GW} / \mathrm{m}^{2}, 2 \mathrm{GW} / \mathrm{m}^{2}$ and $1 \mathrm{GW} / \mathrm{m}^{2}$, respectively. They are limited by maximum beam currents, acceleration voltages and minimum diameters of the electron beam spots. The advantages of electron beam facilities are flexible operation, minimum pulse length $\sim 1 \mathrm{~ms}$ to continuous work and rather homogeneous heat loading on large and well-defined area. The disadvantages are relatively high energy reflection, no possibility to apply magnetic fields around the targets and large penetration depth of the electrons owing to high acceleration voltage. The relatively high acceleration voltage is used in electron beam facilities in order to achieve high power with a limited beam current. The large penetration depth causes volumetric heating rather than surface heating in the targets $(120 \mathrm{keV}$ electrons can penetrate about $100 \mu \mathrm{m}$ in carbon materials). Furthermore, a heat flux of energetic electrons will not be attenuated by vapor clouds that are created in front of target (see Section 4.2.1). Consequently, the erosion rate obtained from electron beam might be overestimated.

Although, carbon based materials (CBMs) are characterized by a high thermal shock resistance and no melting temperature, recent systematic studies showed that they suffer from macroscopic erosion, i.e. brittle destruction (BD) under ITER relevant disruptions condition..$^{99,100,103-108)}$ Timeintegral images shows particle release from fine grain graphite (R6650, Ringsdorf) and CFC (NB31, SepCarb SNECMA) e.g. $2.4 \mathrm{GW} / \mathrm{m}^{2}$ for $4.4 \mathrm{~ms}$. Figure 7 shows a time-integral image during thermal shock loading $(2.4 \mathrm{GW} /$ $\mathrm{m}^{2}$ for $4.4 \mathrm{~ms}$ ) onto CFC. Weight loss measurements as a function of power density, show significant erosion above $1.8 \mathrm{GW} / \mathrm{m}^{2}$ in case of graphite, whereas, negligible weight loss in CFC until $2.5 \mathrm{GW} / \mathrm{m}^{2}{ }^{106)}$ As macroscopic erosion products, cluster of graphitic grains and fiber segments were found. ${ }^{104)}$ These experiments are accompanied by advanced numerical studies. ${ }^{109,110)}$ To observe the dynamic erosion processes, fast diagnostics have been newly developed in JUDITH. The photodiode array equipped with near-infrared cut off filter $(>850 \mathrm{~nm})$ detects light from thermally radiating

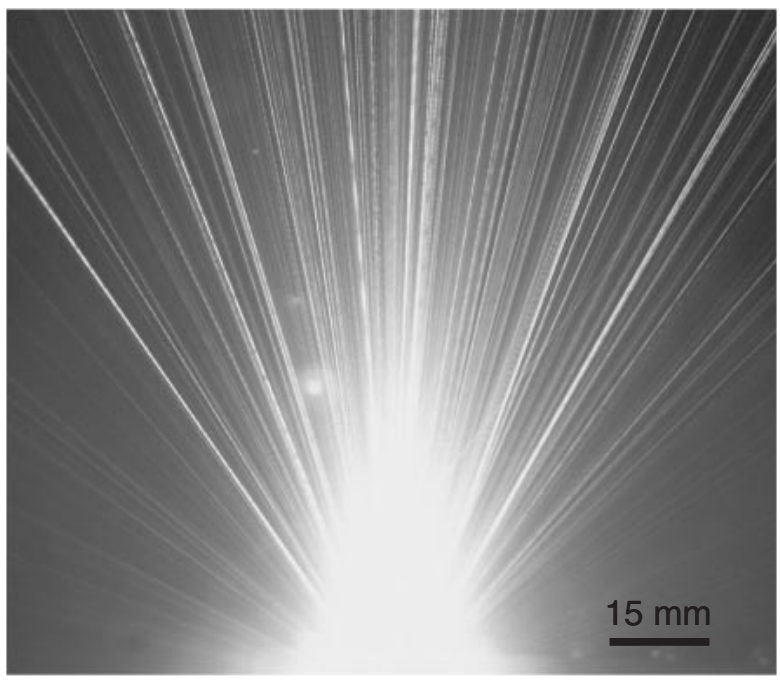

Fig. 7 Macroscopic erosion due to brittle destruction from $\mathrm{CFC}$ at power density of $2.4 \mathrm{GW} / \mathrm{m}^{2}$ for $4.4 \mathrm{~ms}$. The bright lines show the traces of hot particles released from the targets due to brittle destruction.

particles at two positions along the beam axis. By means of the two signals, the speed (estimated to be several $100 \mathrm{~m} / \mathrm{s}$ ), release angles of particles and rotation of the particles were analyzed. ${ }^{100)}$ The photodiodes equipped with interference filters detected selectively a particular line emission such as CII $(589 \mathrm{~nm})$. Time evolution of line emission during the heat loads was obtained. ${ }^{100)}$ As a further development of fast diagnostics in JUDITH, it is planed to install acoustic emission (AE) measurements ${ }^{30,111)}$ to detect micro fracture and destruction processes during thermal shock loads. The other important factor is neutron radiation effect on the erosion. It was shown that the erosion of graphite increased after neutron irradiation $\left(0.35 \mathrm{dpa}\right.$ at $350^{\circ} \mathrm{C}$ and $\left.700^{\circ} \mathrm{C}\right)$ due to a reduction of thermal conductivity. ${ }^{105)}$ It is indispensable to study the influence of radiation damage on the BD as well as sublimation due to overheating caused by reduction of thermal conductivity.

Pure sintered W showed severe cracking after thermal shock tests at room temperature. This is obviously due to the high DBTT (see section 2.3). The severe cracking could be avoided by preheating above the DBTT. ${ }^{105)}$ Thermal shock tests on sintered $\mathrm{W}, \mathrm{W}-1 \% \mathrm{La}_{2} \mathrm{O}_{3}, \mathrm{~W}-26 \% \mathrm{Re}$ and plasma spray $\mathrm{W}$ were tested at around $1.4 \mathrm{GW} / \mathrm{m}^{2}$, for $4.4 \mathrm{~ms}$. In this condition, recrystalization and melting is not avoidable. It was found that sintered $\mathrm{W}$ also suffered from macroscopic erosion, particle release above $0.7 \mathrm{GW} / \mathrm{m}^{2}\left(3.2 \mathrm{GJ} / \mathrm{m}^{2}\right)$ for $4.4 \mathrm{~ms} .{ }^{107)} \mathrm{W}$ dust production due to the macroscopic erosion will be a serious concern in terms of safety considerations.

Various grade of Be materials were tested under disruption and VDE condition. In disruption-like thermal shock tests, the first candidate S65C (Brush Wellman, US) showed less crater depth, cracking depth and thickness of the recrystallization thickness, up to $1 \mathrm{GW} / \mathrm{m}^{2}\left(5.2 \mathrm{MJ} / \mathrm{m}^{2}\right)$ for $5 \mathrm{~ms}$ compared to other grades (DShG200, DShG56 and TR30). ${ }^{112)}$ Erosion of Be increased significantly after irradiation $\left(0.35 \mathrm{dpa}\right.$ at $350^{\circ} \mathrm{C}$ and $\left.700^{\circ} \mathrm{C}\right)$. It was partially due to bubble formation in melted layer caused by gas $(\mathrm{He}, \mathrm{T})$ production during neutron irradiation. As well as the other radiation effects such as reduction of thermal conductivity, radiation 


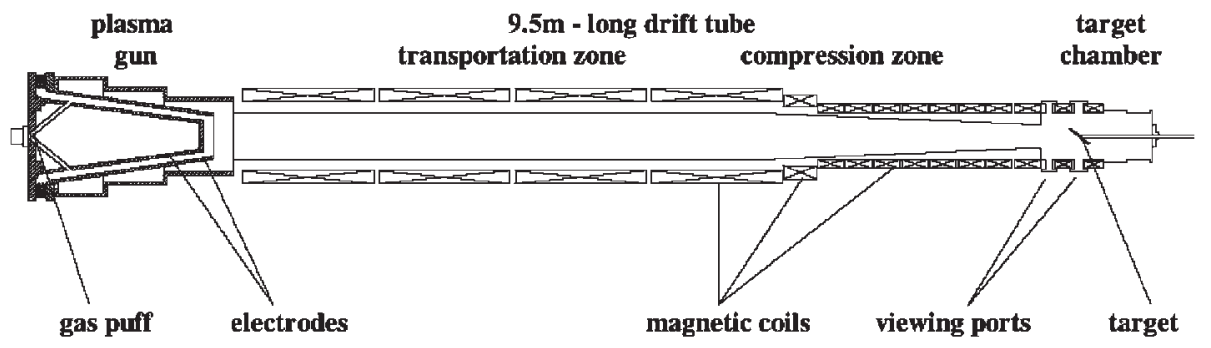

Fig. 8 Basic scheme of MK-200 UG plasma gun facility in Troitsk (Russia). ${ }^{120)}$

induced embrittlement, bubble formation causes strong erosion of Be materials. ${ }^{105)}$

In JEBIS, thermal shock tests on various CFC-based and $\mathrm{W}$-based materials have been performed. ${ }^{50,113)}$ In disruptionsimulating erosion tests on $\mathrm{W}-1 \% \mathrm{La}_{2} \mathrm{O}_{3}$ and pure $\mathrm{W}$ by using the electron beam pulse at $1.25 \mathrm{GW} / \mathrm{m}^{2}$ for $2 \mathrm{~ms}$, weight loss of the $\mathrm{W}-1 \% \mathrm{La}_{2} \mathrm{O}_{3}$ was three times larger than that of pure W. ${ }^{114)}$ The surface observations indicate that the splashing of the melted layer during electron beam pulse occurred only in the $\mathrm{W}-1 \% \mathrm{La}_{2} \mathrm{O}_{3}$, which resulted in the larger weight loss. It was concluded that the results was ascribed to the lower melting point of the doped $\mathrm{La}_{2} \mathrm{O}_{3}$. Repairing techniques of eroded $\mathrm{W}$ tiles has also been developed and tested under thermal shock loads. ${ }^{115)}$ The CVD coating is considered as one of the possible methods for in situ repairing of the W armor. To elucidate the applicability of the CVD coating technique to repair damaged surfaces of $\mathrm{W}$, thermal shock tests were performed on the repaired surface by CVD coating. No delaminating of the CVD coatings was observed on the repaired surfaces at $1.25 \mathrm{GW} / \mathrm{m}^{2}$ for $2 \mathrm{~ms}$ (after removal of the re-solidified layer was necessary before CVD coating). This indicates that the repair of the damaged surface by CVD is effective by removing the re-solidified layer around the loaded surface. ${ }^{115)}$

In OHBIS, thermal shock tests on neutron-irradiated $\mathrm{CFC}$ material have been performed. ${ }^{116,117)}$ 1D-CFC (MFC-1) and 2D-CFC (CX-2002U) were irradiated by neutrons at $0.3 \sim$ $0.5 \mathrm{dpa}$, irradiation temperature of $280 \sim 320^{\circ} \mathrm{C}$ in JMTR. These samples were loaded by thermal shock loads at $0.8 \mathrm{GW} / \mathrm{m}^{2}$ for $25 \mathrm{~ms}$ and $0.5 \mathrm{GW} / \mathrm{m}^{2}$ for $40 \mathrm{~ms}$ (20 $100 \mathrm{MJ} / \mathrm{m}^{2}$ ). By using surface profilometry it was found that the crater depth is not affected by the neutron irradiation. However, the eroded areas, i.e. the diameters of erosion craters increase with neutron dose. Weight loss also increased after neutron irradiation. It was concluded that the higher erosion after neutron irradiation is attributed to a loss of thermal conductivity with neutron fluence due to radiation damage.

\subsection{Transient heat load testing by other heat sources 4.2.1 Thermal shock tests in plasma gun facilities}

The advantages of heat load tests in plasma guns are the small penetration depth which is corresponding to surface heat loads like plasma loading in ITER and the possibility to combine these transient heat loads with magnetic fields. A minor drawback is the inflexible pulse duration: the duration is fixed at several tens of $\mu$ s in plasma guns ${ }^{101,118-122)}$ and several hundred $\mu \mathrm{s}$ in quasi-stationary plasma guns. ${ }^{123)}$ The pulse durations are very short, nevertheless, it is suitable to simulate the initial stage of material response under disruptions. Machine parameters of plasma gun facilities are also found in Ref. 101). Figure 8 shows a plasma gun MK200 UG in Troitsk (Russia). ${ }^{120)}$

Plasma guns are suitable facilities to study the shielding effect under disruption. Due to interaction of energetic plasma pulse with solid material, vaporization of a thin surface layer and a cloud of dense vapor plasma are produced. Vapor plasma acts as a thermal shield stopping the plasma stream and protecting the surface from direct contact with the hot plasma. Target plasma dissipates the incoming energy flux into photon radiation thereby reducing the net power flux reaching onto the target surfaces. Due to the shielding effect, material erosion decreases substantially. The formation and dynamics of vapor shielding have been studied in details and comprehensively summarized in Ref. 101). The major in-situ diagnostics are visible and VUV emission spectrometer, laser scattering diagnostics, bolometer, calorimeter and mass spectrometer. As a result, shielding factors (incident energy/energy used by thermal erosion) estimated to be 500 in graphite, above 1000 in CFC and 100 in $\mathrm{W}$ at an incident energy $Q=15 \mathrm{MJ} / \mathrm{m}^{2}$ in $\mathrm{MK}$ 200UG. ${ }^{119,120)}$ The effect of magnetic field enhances the shielding effect by the confinement of a vapor cloud (vapor shield) in front of the targets. It indicates a considerable reduction of energy influx for plasma disruptions in fusion devices. The speeds of the released particles were estimated to be around $10 \mathrm{~m} / \mathrm{s}$ for graphite and $\mathrm{W}$ by laser scattering measurement. ${ }^{119,120)}$ The speed is one order of magnitude slower than the one measured in the electron beam facility, JUDITH.

Weight loss, characterization of the erosion products and loaded surfaces have been performed routinely. Erosion product (particle) size distribution was found mostly 1-3 $\mu \mathrm{m}$ in graphite and CFC and 1-200 $\mu \mathrm{m}$ for $\mathrm{W}$ droplets in MK200UG. ${ }^{101,119,120)}$ The contribution of BD in graphite, ratio of graphite crystalline in the collected deposits, was estimated to be about $10 \%$ and the contribution of $\mathrm{BD}$ in $\mathrm{CFC}$ was considered to be even less in MK-200UG. ${ }^{119)}$ On the other hand, the size distribution of $\mathrm{W}$ particles had a narrow distribution from 0.1 to $\sim 3 \mu \mathrm{m}$ and CFC had a wide distribution from 0.01 to $\sim 40 \mu \mathrm{m}$ in MKT plasma gun. ${ }^{120}$ ) The results from different facilities are somehow contradictory. It might be caused by different collecting methods. Therefore, it is necessary to develop numerical models that include the exact experimental conditions to correlate experimental results obtained from various facilities and heat sources. 


\subsubsection{Thermal shock tests in high power laser facility}

Plasma disruption loads were simulated on CBMs using pulsed Nd-YAG lasers. Impinging energy densities between 0.2 and $20 \mathrm{MJ} / \mathrm{m}^{2}$ with pulse lengths ranging from 0.1 to $20 \mathrm{~ms}$ were realized. ${ }^{124,125)}$ Presently, these tests are performed at NRG in Petten (the Nederland), where the laser can also be operated inside a hot cell. ${ }^{126)}$ The facility consists of a pulsed high power Nd-YAG laser and a vacuum chamber (down to $10^{-5} \mathrm{~Pa}$ ). Inside the vacuum chamber the laser beam is focused by means of a lens which can be remotely positioned, thus varying the laser spot diameter and incident energy density on the sample. A fast pyrometer, an in-vessel laser power and pulse energy monitor and a calorimeter are used as diagnostics. The absorbed power density of the samples is measured at room temperature in a separate setup. ${ }^{127)}$ Although simulations of transient thermal loads using a laser are less complex compared to other methods, there are difficulties to calibrate the absorbed power density. Presently, the absorbed power density is calculated by an analytical model based on surface temperature increases by assuming homogeneous materials. Moreover, high absorbed power loads is difficult to perform on reflective metal surfaces because of the high reflection.

\section{Summary}

ITER relevant high heat flux testing on plasma facing materials and components are discussed. Electron beam and particle beam facilities are satisfactory to test wide range of static heat loads predicted in ITER. IR heater facilities are possible to simulate moderate heat loads at the first wall mock-ups. Electron beam facilities can also simulate transient heat loads, however, they are not exactly proper to study the dynamics and effects of vapor shield, whereas, plasma gun facilities are advantageous to simulate the vapor shield effects in the early stage of plasma disruption. Thermal shock load tests by high power laser have also been performed.

- The performances of various mock-up designs are evaluated based on the surface temperatures evolution under defined heat loads. Therefore, calibration of surface temperature measurement, i.e. emissivity, and calibration of pre-defined power density must be performed carefully in order to evaluate results obtained in different facilities. Round Robin Tests to access the results from different facilities (electron and particle beam facilities) are carried out and showed fairly good agreement.

- Divertor components (W and CFC mock-ups) are resistant to power density up to around $20 \mathrm{MW} / \mathrm{m}^{2}$. CFC monoblock, W macrobrush, showed excellent performances in un-irradiated stage, however, limited performances after irradiation $(<1 \mathrm{dpa})$. Present concern is radiation-induced degradation. W monoblock showed rather benign performances even after irradiation.

- Small and medium scale first wall mock-ups (Be mockups) that can withstand at a power density of $0.5 \mathrm{MW} /$ $\mathrm{m}^{2}$ are available. Scaling up of Be mock-ups is still a technological challenge. Non-destructive examination of the Be mock-up is needed to be developed.
- In-pile tests provide important data on synergistic effects of neutron irradiation and cyclic heat loads.

- Thermal shock tests in electron beam facilities indicate that all materials suffered from melting and evaporation or sublimation, and brittle destruction in ITER relevant disruption conditions. Nevertheless, CFC shows negligible erosion up to $2.5 \mathrm{GW} / \mathrm{m}^{2}$ for $4.4 \mathrm{~ms}$. The damage and erosion rate tend to increase after neutron irradiation.

- Results from plasma gun facilities indicate that vapor shield effects significantly reduce energy influx onto the targets and contribute to a reduction of the material damage and erosion.

- On supporting by various fast diagnostics and post mortem analyses in transient heat load experiments, numerical model is necessary to be developed for understanding the experimental findings from different heat sources.

- Transient heat load experiments focused on ELMs are urgently needed. Material performances under ELM condition started only recently.

\section{Acknowledgements}

Authors wish to thank Dr. J. Linke from Forschungszentrum Jülich Germany, for the helpful comments, suggestions and valuable discussion. They also would like to acknowledge Dr. M. Rödig from Forschungszentrum Jülich, Dr. M. Uchida from NGK Japan and Dr. M. Akiba from Japan Atomic Energy Research Institute Japan, for fruitful discussions.

\section{REFERENCES}

1) G. Federici, C. H. Skinner, J. N. Brooks, J. P. Coad, C. Grisolia, A. A. Haasz, A. Hassanein, V. Philipps, C. S. Pitcher, J. Roth, W. R. Wampler and D. G. Whyte: Nucl. Fusion 41 (2001) 1967-2137.

2) G. Federici, P. Andrew, P. Barabaschi, J. Brooks, R. Doerner, A. Geier, A. Herrmann, G. Janeschitz, K. Krieger, A. Kukushkin, A. Loarte, R. Neu, G. Saibene, M. Shimada, G. Strohmayer and M. Sugihara: J. Nucl. Mater. 313-316 (2003) 11-22.

3) V. Barabash, G. Federici, J. Linke and C. H. Wu: J. Nucl. Mater. 313316 (2003) 42-51.

4) V. Philipps, J. Roth and A. Loarte: Plasma Phys. Contl. Fusion 45 (2004) A17-A30.

5) R. Tivey, M. Akiba, D. Driemeyer, I. Mazul, M. Merola and M. Ulrikson: Fusion Eng. Des. 60 (2001) 219-229.

6) M. Merola, G. Vieider, M. Bet, I. Bobin Vastra, L. Briottet, P. Chappuis, K. Cheyne, G. Dell'Orco, D. Duglue, R. Duwe, S. Erskine, F. Escourbiac, M. Febvre, M. Grattarola, F. Moreschi, A. Orsini, R. Pamato, L. Petrizzi, L. Plöchl, B. Riccardi, E. Rigal, M. Rödig, J. F. Salavy, B. Schedler, J. Schlosser, S. Tähtinen, R. Vesprini, E. Visca and C. H. Wu: Fusion Eng. Des. 56-57 (2001) 173-178.

7) M. Merola, M. Akiba, V. Barabash and I. Mazul: J. Nucl. Mater. 307311 (2002) 1524-1532.

8) R. E. Nygren: Fusion Eng. Des. 60 (2002) 547-564.

9) R. Aymar and International Team: J. Nucl. Mater. 307-311 (2002) $1-9$.

10) ITER materials assessment report, 2001, G74 MA 10 01-07-11 W 0.2.

11) T. Hatano, T. Kuroda, V. Barabash and M. Enoeda: J. Nucl. Mater. 307-311 (2002) 1537-1541.

12) M. Uchida, E. Ishitsuka, T. Hatano, V. Barabash and H. Kawamura: J. Nucl. Mater. 307-311 (2002) 1533-1536.

13) H. Yamada, M. Uchida, M. Uda, T. Iwadachi, M. Nakamichi and H. Kawamura: J. Nucl. Mater. 329-333 (2004) 885-888. 
14) C. Boudot, I. Bobin-Vastra, P. Lorenzetto, D. Conchon, A. Cottin, J. Jacquinot, D. Cauvin and M. Febvre: Fusion Eng. Des. 66-68 (2003) 347-352.

15) A. Gervash, R. Giniyatulin, V. Komarov, I. Mazul, N. Litunovsky, A. Ganenko, A. Vainerman, V. Fedotov, D. Davydov and R. Zalavutdinov: Fusion Eng. Des. 39-40 (1998) 543-549.

16) V. K. Gagen-Torn, I. R. Kirillov, V. N. Litunovsky, I. V. Mazul, I. B. Ovchinnikov, Yu. G. Prokofjev, G. L. Saksagansky and V. A. Tinov: Proc. 18th Symposium on Fusion Technology (SOFT), Karlsruhe Germany, (1994) 363-366.

17) R. N. Giniyatulin, V. L. Komarov, E. G. Kuzmin, A. N. Makhankov, I. V. Mazul, N. A. Yablokov and A. N. Zhuk: Fusion Eng. Des. 39-40 (1998) 543-549.

18) Plant Technical Documnet G AO FDR 1 01-07-13 R1.0.

19) R. G. Castro, P. W. Stanek, K. E. Elliott, J. D. Cotton and R. D. Watson: J. Nucl. Mater. 226 (1995) 170-177.

20) R. G. Castro, A. H. Bartlett, K. J. Hollis and P. D. Fields: Fusion Eng. Des. 37 (1997) 243-252.

21) D. L. Youchison, J. M. McDonald and L. S. Wold: "High heat flux testing capabilities at Sandia National Lanoratories", in R. D. Boyd, A. J. Ghajar: "Heat transder in high heat flux systems", (ASME Book No. G00956, 1994).

22) R. G. Castro, K. E. Elliot, R. D. Watson, D. L. Youchison and K. T. Slattery: J. Nucl. Mater. 258-263 (1998) 252-257.

23) W. Daenner, M. Merola, P. Lorenzetto, A. Peacock, I. Bobin-Vastra, L. Briottet, B. Bucci, D. Conchon, A. Erskine, F. Escourbiac, M. Febvre, M. Grattarola, C. G. Hjorth, G. Hofmann, A. Ilzhoefer, K. Lill, A. Lind, J. Linke, W. Richards, E. Rigal, M. Roedig, F. SaintAntonin, B. Schedler, J. Schlosser, S. Tahtinen and E. Visca: Fusion Eng. Des. 61-62 (2002) 61-70.

24) M. Seki, R. Matera, F. Tavassoli, J. Davis and D. Smith: J. Nucl. Mater. 271\&272 (1999) 569-577.

25) C. H. Wu, C. Alessandrini, P. Bonal, H. Grote, R. Moormann, M. Rödig, J. Roth, H. Werle and G. Vieider: J. Nucl. Mater. 258-263 (1998) 833-838.

26) M. Akiba, M. Araki, K. Nakamura, S. Satoh, S. Suzuki, M. Dairaku, K. Yokoyama and Y. Ohara: Proc. 19th Symp. on Fusion Technology (SOFT), Lisbon, Portugal (1996) 307-310.

27) T. D. Marshall, R. J. Pawelko, R. A. Anderl, G. R. Smolik, B. J. Merrill, R. L. Moore and D. A. Petti: Fusion Eng. Des. 69 (2003) 663 667.

28) M. Merola, W. Dänner, J. Palmer, G. Vielder, C. H. Wu and the EU ITER Participating Team: Fusion Eng. Des. 66-68 (2003) 211-217.

29) V. Barabash, M. Akiba, J. P. Bonal, G. Federici, R. Matera, K Nakamura, H. D. Pacher, M. Rödig, G. Vieider and C. H. Wu: J. Nucl. Mater. 258-263 (1998) 149-159.

30) P. Majerus, J. Compan, T. Hirai, J. Linke and R. May: Acoustic emission studies on fracture behaviour of CFC-materials under various loads, Proc. 26th Eur. Conf. on Acoustic Emission Testing, Berlin, 2004, to appear.

31) J. P. Bonal, C. H. Wu and D. Gosset: J. Nucl. Mater. 307-311 (2002) 100-105.

32) T. Hino and M. Akiba: Fusion Eng. Des. 49-50 (2000) 97-105.

33) M. Merola, I. Bobin-Vastra, A. Cardella, M. Febvre, L. Giancarli, L. Plöchl, J. F. Salavy, A. Salito, B. Schedler and G. Vieider: Fusion Eng. Des. 49-50 (2000) 289-294.

34) M. Onozuka, S. Hirai, K. Kikuchi, Y. Oda and K. Shimizu: J. Nucl. Mater. 329-333 (2004) 1553-1557.

35) P. Appendino, V. Casalegno, M. Ferraris, M. Grattarola, M. Merola and M. Salvo: Fusion Eng. Des. 66-68 (2003) 225-229.

36) P. Appendino, M. Ferraris, V. Casalegno, M. Salvo, M. Merola and M. Grattarola: J. Nucl. Mater. 329-333 (2004) 1563-1566.

37) I. Smid, M. Akiba, G. Vieider and L. Plöchl: J. Nucl. Mater. 258-263 (1998) 160-172.

38) Y. Kitsunai, H. Kurishita, H. Kayano, Y. Hiraoka, T. Igarashi and T. Takida: J. Nucl. Mater. 271\&272 (1999) 423-428.

39) Y. Ishijima, H. Kurishita, K. Yubuta, H. Arakawa, M. Hasegawa, Y. Hiraoka, T. Takida and K. Takebe: J. Nucl. Mater. 329-333 (2004) $775-779$.

40) G. Pintsuk, S. E. Brünings, J.-E. Döring, J. Linke, I. Smid and L. Xue: Fusion Eng. Des. 66-68 (2003) 237-240.
41) J.-E. Döring, R. Vaßen, G. Pintsuk and D. Stöver: Fusion Eng. Des. 66-68 (2003) 259-263.

42) G. Pintsuk: "Integration eines funktionell gradierten $W / \mathrm{Cu}$ - ̈̈bergangs für Divertorkomponenten von Fusionsanlagen", Berichte des Forschungszentrum Julich, 4148, ISSN 0944-2952, October 2004. (in German).

43) K. T. Slattery, B. C. Odegard Jr, T. N. McKechnie and R. D. Watson: IEEE (1998) 888-891.

44) B. Riccardi, A. Pizzuto, L. Bertamini, M. Diotalevi and G. Vieider: IEEE (1998) 910-913.

45) K. Tokunaga, N. Yoshida, Y. Kubota, N. Noda, Y. Imamura, T. Oku, A. Kurumada, T. Sogabe, T. Kato and L. Plöchl: Fusion Eng. Des. 4950 (2000) 371-376.

46) H. Maier, S. Kötterl, K. Kriger, R. Neu, M. Balden and ASDEX Upgrade-Team: J. Nucl. Mater. 258-263 (1998) 921-926.

47) T. Tanabe, M. Wada, T. Ohgo, V. Philipps, M. Rubel, A. Huber, J. von Seggern, K. Ohya, A. Pospieszczyk, B. Schweer and TEXTOR team: J. Nucl. Mater. 283-287 (2000) 1128-1133.

48) S. Deschka, C. Garcia-Rosales, W. Hohenauer, R. Duwe, E. Gauthier, J. Linke, M. Lochter, W. Mallener, L. Plöchl, P. Rödhammer and A. Salito: J. Nucl. Mater. 233-237 (1996) 645-649.

49) J. Boscary, S. Suzuki, K. Nakamura, T. Suzuki and M. Akiba: Fusion Eng. Des. 39-40 (1998) 537-542.

50) K. Nakamura, S. Suzuki, T. Tanabe, M. Dairaku, K. Yokoyama and M. Akiba: Fusion Eng. Des. 39-40 (1998) 295-301.

51) K. Ezato, M. Dairaku, M. Taniguchi, K. Sato and M. Akiba: J. Nucl. Mater. 307-311 (2002) 144-148.

52) M. Rödig, R. Duwe, W. Kühnlein, J. Linke, M. Scheerer, I. Smid and B. Wiechers: J. Nucl. Mater. 258-263 (1998) 967-971.

53) S. Taehtinen, H. Jeskanen and P. Kaupponen: Ultrasonic and metallographic examimation of ITER vertical target prototype, VTT Report BVAL62-011099, March 2001.

54) F. Escourbiac and J. Schlosser: Critical heat flux and thermal hydraulic of representative elements, non destructive testing, calibrated defects, heat load influence, CEA Report CFP/NTT-2000.030, December 2000.

55) A. Kapoustina, T. Hirai, J. Linke and M. Rödig: Phys. Scripta T111 (2004) 181-183.

56) H. Traxler, J. Schlosser, A. Durocher, B. Schedler, T. Huber and A. Zabernig: Phys. Scripta T111 (2004) 203-205.

57) M. Merola, P. Chappuis, F. Escourbiac, M. Grattarola, H. Jeskanen, P. Kauppinen, L. Ploechl, B. Schedler, J. Schlosser, I. Smid, S. Taehtinen, R. Vesprini, E. Visca and A. Zabernig: Fusion Eng. Des. 61-62 (2002) 141-146.

58) M. Merola, C. H. Wu and the EU ITER Participating Team: Phys. Scripta T111 (2004) 152-156.

59) M. Rödig, M. Akiba, P. Chappuis, R. Duwe, M. Febvre, A. Garavash, J. Linke, N. Litounovsky, S. Suzuki, B. Wiechers and D. L. Youshison: Fusion Eng. Des. 51-52 (2000) 715-722.

60) M. Rödig, I. Bobin-Vastra, S. Cox, F. Escoubiac, A. Geravash, A Kapoustina, W. Kuehnlein, V. Kuznetsov, M. Merola, R. Nygren and D. L. Youchison: submitted to 24th SOFT, 2004, Venice Italy.

61) M. Rödig, W. Kühnlein, J. Linke, M. Merola, E. Rigal, B. Schedler and E. Visca: Fusion Eng. Des. 61-62 (2002) 135-140.

62) S. Shimakawa, N. Sakamoto, K. Satoh, M. Akiba and H. Kawamura: J. Nucl. Mater. 233-237 (1996) 1582-1585.

63) R. Duwe, W. Kühnlein and H. Münstermann: Proc. 18th Symposium on Fusion Thechnology (SOFT), Karlsruhe Germany, (1994) 355358.

64) M. Akiba, M. Araki, S. Suzuki, S. Tanaka, M. Dairaku, M. Seki and K. Yokoyama: Plasma devices and operations 1 (1991) 205-12.

65) Y. Kubota, et al.: "Development of high heat flux components in LHD”, Proc. Of the ASME Heat Transfer Division, HTD-Vol. 317-1 (1995) 159.

66) K. Tokunaga, K. Matsumoto, Y. Miyamoto, T. Muroga and N. Yoshida: J. Nucl. Mater. 212-215 (1994) 1323-1328.

67) M. Diotalevi and M. Febre: Ph. Chappuis, "Evolution of Framatome and CEA High Thermal Flux Station for Fusion Technology Experiments Needs", Proc. 19th Symposium on Fusion Thechnology (SOFT), Lisbon Portugal, (1996) p. 491-494.

68) J. H. Wu, F. Zang and Z. Xu et al.: "Research of high heat flux for 
divertor materials", Chinese J. Nucl. Sci. Eng. 23 (2003) 132.

69) M. Rödig, R. Duwe, J. Linke, R. H. Qian and A. Schuster: IEEE (1998) 865-868.

70) M. Rödig, R. Conrad, H. Derz, R. Duwe, J. Linke, A. Lodato, M. Merola, G. Pott, G. Vieider and B. Wiechers: J. Nucl. Mater. 283-287 (2000) 1161-1165.

71) M. Rödig, R. Duwe, J. Linke, G. Pott and B. Wiechers: Phys. Scripta T81 (1999) 101-103.

72) M. Rödig, R. Duwe, W. Kühnlein, J. Linke, M. Merola, B. Schedler, G. Vieider and E. Visca: Fusion Eng. Des. 56-57 (2001) 417-420.

73) M. Rödig, E. Ishistuka, A. Garacash, H. Kawamura, J. Linke, N litunovski and M. Merola: J. Nucl. Mater. 307-311 (2002) 53-59.

74) M. Rödig, W. Kühnlein, J. Linke, D. Pitzer, M. Merola, E. Rigal, B. Schedler and E. Visca: J. Nucl. Mater. 329-333 (2004) 766-770.

75) H. Takatsu, K. Sato, K. Hamada, M. Nakahira, S. Suzuki, H. Nakajima, T. Kuroda, T. Nishitani, T. Shikama and W. Shu: J. Nucl. Mater. 329-333 (2004) 178-182.

76) K. Ezato, S. Suzuki, K. Sato and M. Akiba: J. Nucl. Mater. 329-333 (2004) 820-824.

77) J. Boscary, M. Araki, S. Suzuki, K. Ezato and M. Akiba: Fusion Technology 35 (1999) 289-296.

78) E. Ishitsuka, M. Uchida, K. Sato, M. Akiba and H. Kawamura: Fusion Eng. Des. 56-57 (2001) 421-425.

79) M. Merola, L. Plöchl, Ph. Chappuis, F. Escourbiac, M. Grattarola, I. Smid, R. Tivey and G. Vieider: J. Nucl. Mater. 283-287 (2000) 10681072 .

80) K. Ezato, S. Suzuki, K. Sato, M. Taniguchi, M. Hanada, M. Araki and M. Akiba: Fusion Eng. Des. 56-57 (2001) 291-295.

81) K. Ezato, M. Dairaku, M. Taniguchi, K. Sato, S. Suzuki, M. Akiba, C. Ibbott b and R. Tivey: "Development of ITER Divertor Vertical Target with Annular Flow Concept, Part I - Thermal hydraulic characteristics of annular swirl tube," To be published in Fusion Science and Technology, Oct. 2004.

82) K. Tokunaga, S. Tamura, N. Yoshida, K. Ezato, M. Taniguchi, K. Sato, S. Suzuki and M. Akiba: J. Nucl. Mater. 329-333 (2004) $757-$ 760.

83) G. Düsing, H. Altmann, H. Falter, A. Goede, R. Haange, R. S. Hemsworth, P. Kupschus, D. Stork and E. Thompson: Fusion Technology 11 (1987) 163-203.

84) G. Hofmann and E. Eggert: First wall test facility FIWATKA, KfK 5381, September 1994.

85) W. Dänner, A. Cardella, K. Ioki, R. Mattas, Y. Ohara and Y. Strebkov: Fusion Eng. Des. 55 (2001) 205-217.

86) H. Greuner, B. Böswirth, J. Boscary, G. Hofmann, B. Mendelevitch, H. Renner and R. Rieck: Fusion Eng. Des. 66-68 (2003) 447-452.

87) G. Dell'Orco, P. Lorenzetto, A. Malavasi, G. Polazzi, M. Simoncini, G. Venturi and D. Zito: Fusion Eng. Des. 61-62 (2002) 117-122.

88) G. Dell'Orco, P. Lorenzetto, I. Alessandrini, G. Bernardi, A. Malavasi, A. Malavasi and G. Venturi: Fusion Eng. Des. 66-68 (2003) 311-316.

89) G. Dell'Orco: personal communication.

90) D. Valenza, H. Greuner, G. Hofmann, S. Kötterl, J. Roth and H. Bold: J. Nucl. Mater. 307-311 (2002) 89-94.

91) P. Lorenzetto, A. Cardella, P. Chappuis, W. Daenner, A. Erskine, M. Fèbre, G. Hofmann, P. Le Gallo, H. Stamm and S. Tähtinen: Fusion Eng. Des. 49-50 (2000) 263-268.

92) M. Rödig, E. Ishitsuka, A. Gervash, H. Kawamura, J. Linke, N. Litunovski and M. Merola: J. Nucl. Mater. 307-311 (2002) 53-59.

93) Y. Strebkov and V. Belyakov: Fusion Eng. Des. 61-62 (2002) 47-59.

94) N. Litunovsky, V. Komarov and I. Mazul: Fusion Eng. Des. 51-52 (2000) 803-807.

95) A. Gervash, R. Giniyatulin and I. Mazul: Fusion Eng. Des. 46 (1999) 229-235.

96) J. Linke, T. Hirai, M. Rödig and L. Singheiser: Fusion Sci. Tech. 46 (2004) 142-151.

97) R. Nygren, D. Youshison, M. Ulrickson, J. McDonald and T. Lutz: "Simulation of ELMs in HHF tests of W rod armor" presented at 16th International conference on plasma surface interaction in controlled fusion devices, Portland Maine USA, May 2004.

98) A. Zhitlukhin, N. Arkhipov, R. Giniyatulin, N. Klimov, I. Landman, A. Loarte, M. Merola, V. Podkovyrov, V. Safronov and G. Federici:
"Effects of ELMs and disruptions on ITER divertor armor materilas", presented at 16th International conference on plasma surface interaction in controlled fusion devices, Portland Maine USA, May 2004

99) T. Hirai, J. Linke, W. Kühnlein, G. Sergienko and S. Brezinsek: J. Nucl. Mater. 321 (2003) 110-114.

100) T. Hirai, S. Brezinsek, W. Kühnlein, J. Linke and G. Sergienko: Phys Scripta T111 (2004) 163-166.

101) V. Safronov, N. Arkhipov, V. Bakhtin, S. Kurkin, F. ScaffidiArgentina, D. Toporkov, S. Vasenin, H. Wuerz and A. Zhitlukhin: J. Nucl. Mater. 290-293 (2001) 1052-1058.

102) J. Linke, H. Bolt, R. Duwe, W. Kühnlein, A. Lodato, M. Rödig, K. Schöpflin and B. Wiechers: J. Nucl. Mater. 283-287 (2000) 1152 1156

103) H. Bolt, J. Linke, H. J. Penkalla and E. Tarret: Phys. Scripta T81 (1999) 94-97.

104) J. Linke, M. Rubel, J. A. Malmberg, J. R. Darke, R. Duwe, H. J. Penkalla, M. Rödig and E. Wessel: Phys. Scripta T91 (2001) 36-42.

105) J. Linke, M. Akiba, R. Duwe, A. Lodato, H.-J. Penkalla, M. Rödig and K. Schöpflin: J. Nucl. Mater. 290-293 (2001) 1102-1106.

106) J. Linke, S. Amouroux, E. Berthe, Y. Koza, W. Kühnlein and M. Rödig: Fusion Eng. Des. 66-68 (2003) 395-399.

107) Y. Koza, E. Berthe, E. Lehmann, J. Linke, M. Rödig, E. Wessel and L. Singhwiser: J. Nucl. Mater. 329-333 (2004) 706-710.

108) Y. Koza, S. Amouroux, B. N. Bazylev, E. Berthe, W. Kühnlein, J. Linke, H. J. Penkalla and L. Singheiser: Phys. Scripta T111 (2004) 167-172.

109) S. Pestchanyi and H. Würz: Phys. Scripta T91 (2001) 84.

110) B. N. Bazylev, Y. Koza, I. S. Landman, J. Linke, S. E. Pestchanyi and H. Würz: Phys. Scripta T111 (2004) 213-217.

111) M. Enoki, M. Watanabe, P. Chivavibul and T. Kishi: Sci. Tech. Advanced Mater. 1 (2000) 157-165.

112) M. Rödig, R. Duwe, J. Linke, R. H. Qian and A. Schuster: IEEE (1998) 865-868.

113) K. Nakamura, S. Suzuki, M. Dairaku, K. Yokoyama, Y. Okumura, T. Suzuki, R. Jimbou, V. Bandourko and M. Akiba: J. Nucl. Mater. 258263 (1998) 828-832.

114) M. Taniguchi, K. Nakamura, K. Sato, K. Ezato, K. Yokoyama and M. Akiba: Fusion Tech. 39 (2001) 890-893.

115) M. Taniguchi, K. Sato, K. Ezato, K. Yokoyama and M. Akiba: J. Nucl. Mater. 307-311 (2002) 719-722.

116) M. Uda, E. Ishitsuka, K. Sato, M. Akiba, Yamamura and H Kawamura: Phys. Scripta T81 (1999) 98-100.

117) K. Sato, E. Ishitsuka, M. Uda, H. Kawamura, S. Suzuki, M. Taniguchi, K. Ezato and M. Akiba: J. Nucl. Mater. 283-287 (2000) 1157-1160

118) N. Arkhipov, V. P. Bakhtin, S. M. Kurkin, V. M. Safronov, D. A Toporkov, S. G. Vasenin, H. Wuerz and A. M. Zhitlukhin: J. Nucl. Mater. 233-237 (1996) 767-770.

119) N. Arkhipov, V. Bakhtin, S. Kurkin, V. Safronov, D. Toporkov, S. Vasenin, A. Zhitlukhin and H. Würz: Fusion Eng. Des. 49-50 (2000) 151-156.

120) N. Arkhipov, V. Bakhtin, V. Barsuk, S. Kurkin, E. Mironova, G. Piazza, V. Safronov, F. Scaffidi-Argentina, D. Toporkov, S. Vasenin, H. Würz and A. Zhitlukhin: J. Nucl. Mater. 307-311 (2002) 1364 1368.

121) M. I. Guseva, V. M. Gureev, B. N. Kolbasov, S. N. Korshunov, Yu. V. Martynenko, V. G. Stolyarova, V. M. Strunnikov and V. I. Vasiliev: Fusion Eng. Des. 66-68 (2003) 389-394.

122) T. Burtseva, A. Hassanien, I. Ovchinnikov and V. Titov: J. Nucl. Mater. 290-293 (2001) 1059-1063.

123) V. G. Belan, V. F. Levashov, V. S. Maynashev, A. D. Muzichenko and V. L. Podkovirov: J. Nucl. Mater. 233-237 (1996) 763-766.

124) A. Benz, H. Nickel, A. Naoumidis, S. Menzel, K. Wetzig and R. Rossek: J. Nucl. Mater. 212-215 (1994) 1318-1322.

125) J. G. van der Laan: J. Nucl. Mater. 162-164 (1989) 964-969.

126) E. V. van Osch, M. G. Horsten, M. I. de Vries, W. van Witzenburg, R. Conrad, G. Sordon and G. P. Tartaglia: J. Nucl. Mater. 233-237 (1996) 1541-1546.

127) E. V. van Osch and J. G. van der Laan: J. Nucl. Mater. 220-222 (1995) 781-784. 